\title{
The Feminine Value In Nietzsche Echo, Baubo and Ariadne
}

\author{
By Sarah Nichole Patterson
}

\author{
A thesis submitted to \\ the Faculty of Graduate Studies and Research \\ in partial fulfillment of \\ the requirements for the degree of \\ Master of Arts
}
Department of Political Science
Carleton University
Ottawa, Ontario
Canada

(C) Sarah Nichole Patterson, 2005 


$\begin{array}{ll}\begin{array}{l}\text { Library and } \\ \text { Archives Canada }\end{array} & \begin{array}{l}\text { Bibliothèque et } \\ \text { Archives Canada }\end{array} \\ \begin{array}{l}\text { Published Heritage } \\ \text { Branch }\end{array} & \begin{array}{l}\text { Direction du } \\ \text { Patrimoine de l'édition }\end{array} \\ \begin{array}{l}\text { 395 Wellington Street } \\ \text { Ottawa ON K1A ON4 }\end{array} & \begin{array}{l}\text { 395, rue Wellington } \\ \text { Ottawa ON K1A ON4 } \\ \text { Canada }\end{array}\end{array}$

Your file Votre référence

ISBN: 0-494-13419-4

Ourfile Notre référence

ISBN: 0-494-13419-4

NOTICE:

The author has granted a nonexclusive license allowing Library and Archives Canada to reproduce, publish, archive, preserve, conserve, communicate to the public by telecommunication or on the Internet, loan, distribute and sell theses worldwide, for commercial or noncommercial purposes, in microform, paper, electronic and/or any other formats.

The author retains copyright ownership and moral rights in this thesis. Neither the thesis nor substantial extracts from it may be printed or otherwise reproduced without the author's permission.
AVIS:

L'auteur a accordé une licence non exclusive permettant à la Bibliothèque et Archives Canada de reproduire, publier, archiver, sauvegarder, conserver, transmettre au public par télécommunication ou par l'Internet, prêter, distribuer et vendre des thèses partout dans le monde, à des fins commerciales ou autres, sur support microforme, papier, électronique et/ou autres formats.

L'auteur conserve la propriété du droit d'auteur et des droits moraux qui protège cette thèse. $\mathrm{Ni}$ la thèse ni des extraits substantiels de celle-ci ne doivent être imprimés ou autrement reproduits sans son autorisation.
In compliance with the Canadian

Privacy Act some supporting forms may have been removed from this thesis.

While these forms may be included in the document page count, their removal does not represent any loss of content from the thesis.
Conformément à la loi canadienne sur la protection de la vie privée, quelques formulaires secondaires ont été enlevés de cette thèse.

Bien que ces formulaires aient inclus dans la pagination, il n'y aura aucun contenu manquant.

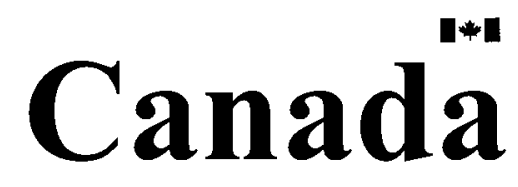




\begin{abstract}
The question "Suppose truth to be a woman-What?" posited by Nietzsche in his preface to Beyond Good and Evil leads the reader to consider the conversation occurring within his work between the concepts of 'woman' and 'truth.' This consideration forces us - as readers-to address Nietzsche's label as foremost misogynist in the philosophical community. By addressing Nietzsche's misogyny we come to the realisation that 'woman,' like 'God' is a conjecture created by man. The female sex merely forms herself around this creation in order to become 'woman' as she is defined by the feminine gender. This is, according to Nietzsche, a perversion of the female sex and, subsequently, subject to Nietzsche's philosophical project-the trans-valuation of all values actualised through the development of new myths.
\end{abstract}




\section{Table of Contents}

Introduction

Nietzsche, misogyny and mendaciousness

Chapter One

The prehistory of gender

Chapter Two

Woman's perversion: reflections of Echo

Chapter Three

Deconstructing 'woman': Baubo's ridiculous exposure

Chapter Four

Autonomous 'woman': silent Ariadne

Conclusion

The androgynisation of the species

Bibliography 


\section{Introduction}

Nietzsche, Misogyny and Mendaciousness

'Supposing truth to be a woman-What?' Our first response to this strange quote by Nietzsche is an echoing of the philosopher: we begin by repeating the question 'What?' What does Nietzsche mean by this statement? By parsing this quote into its constituent elements we shall hopefully gain insight into our experience of it.

To begin, this statement occurs in three moments: 1) supposition, 2) metaphor, and 3) questioning. The first moment is one of possibility and doubt. We are forced into a position of sceptical disbelief. This request of Nietzsche's is all the more stressful given the concept he is asking us to be sceptical of: truth. If we are believers in truth the doubt required in this moment is impossible to consider. If we believe in truth, there can be no supposition of truth. If we believe in truth this moment ends at its beginning. If, however, we have doubts, then we can accept Nietzsche's supposition. In order to experience this moment we need to be sceptical of truth. Nietzsche's statement, therefore, presupposes an audience of sceptics. 
The second moment is an act of creation which occurs outside the boundaries of language. This is an act of magic. Within the space of this moment we take hold of the concept (and word) 'truth' and transform it into the concept (and word) 'woman'. The magic of metaphor - which is the magic of this second moment - lies in the ineffability of concepts. Through metaphor we are able to carry the ineffable into the realm of language-we make the unspeakable speak. But in this act of magic we are faced with an odd situation: whereas the first moment is experienced through scepticism the second requires the suspension of disbelief. We need to believe in the magical act of metaphor in order to experience this second moment. We therefore move from the moment of doubt into the moment of magical belief.

The third moment reminds us of the first. We may be tempted to suggest that rather than tracing a linear path we have run a circle. Yet this third moment is different from the first in that it is overarching. This third moment of questioning expresses the doubt of the first moment in that it questions this doubt. This third moment also questions the suspension of disbelief of the second moment. We are made aware through the single question of 'what?' of the passing and experience of the first two moments. It is not until we have entered the third moment of questioning that we understand what came before. This final moment cannot be circular in that it cloaks the first two moments within it, thus we are pushed beyond and outside of the first two moments. Questioning the proposition of the first two moments leads us to question the reality of our experience of them, while not denying that the experience did in fact occur. 
The experience of questioning is integral to our understanding of the statement from Nietzsche's prologue to Beyond Good and Evil. We are taught in this statement that we must question both 'truth' and 'woman'; and that this questioning is not only of the concepts as independent entities, but, as well concerns their relations in concert and conversation with one another. This is our goal-a journey of consideration of the concepts of 'truth' and 'woman' for Nietzsche.

But before we begin, let us address the oddities raised by the above analysis. The first oddity is the importance of 'woman' in this lesson. Nietzsche is, after all, philosophy's favourite misogynist ${ }^{1}$. How do we accept-and therefore consider—Nietzsche's concept of woman? Is the relationship between 'truth' and 'woman' developed by Nietzsche nothing more than a spoof? The second oddity concerns the definition of truth and comes as a result of the first. Truth is, arguably, the fundamental concern of philosophy and certainly not a concept to be taken lightly. Philosophers have made it their goal to decipher what 'Truth' is in the face of the many things which masquerade as truths. Is Nietzsche mocking truth in the above quote? How does Nietzsche view truth? Effectively, we must address the possibility that this quote is nothing more than the punch line to a colossal and unwritten joke. To this end these two primary issues must be addressed before we engage ourselves any further.

\footnotetext{
1 'Nietzsche, the misogynist' has entered the lexicon of popular culture. The opinion is bolstered not only by the feminist community (and the philosophical community) but now is considered a 'fact' by the world at large. Kathleen Marie Higgins provides interesting insight into the state of this opinion within the feminist philosophical discourse in her article entitled "Gender in the Gay Science' published in Philosophy and Literature 19.2 (1995) 227-247
} 
In order to ascertain whether or not we can accept Nietzsche's concept of woman we must first understand what 'woman' is for Nietzsche. This is a more difficult question than it would first appear to be. A very personal philosopher, Nietzsche wrote himself and wrote for himself. In order to understand the man's philosophy, we must as well understand the man. We must, therefore, address Nietzsche's relations with women to understand his relationship with the concept 'woman.'

At the age of thirty-six, Karl Ludwig Nietzsche, the country parson, dies from a 'softening of the brain.' The following year his young son Ludwig Joseph follows him ${ }^{2}$. His other son, Friedrich Wilhelm (now six), will come of age in a house of women ${ }^{3}$. As the teenaged Nietzsche states in the first of many youthful autobiographies, he regards himself as "by and large...in charge of [his] own upbringing...[having] had to do without the strict and senior guidance of a male intellect ${ }^{4} . "$ This statement by the fourteen-year old Friedrich illustrates his view of his mother's role in his upbringing. Nietzsche's consideration of his mother's position in the 'Bildungsroman' of his life increases in complexity as Nietzsche ages. The convoluted and cryptic nature of this relationship is exemplified in Nietzsche's last explicitly autobiographical work, Ecce Homo (1889), when he states the riddle of his life: he is "already dead as [his] father, while as [his]

\footnotetext{
${ }^{2}$ Rüdiger Safranski. "Chronicle of Nietzsche's life” in Nietzsche: A Philosophical Biography. New York: Norton, 2003. p 351.

${ }^{3}$ The Nietzsche household consisted of Friedrich, his sister Elisabeth, his mother Franziska, his paternal grandmother, and two maiden aunts. (R.J. Hollingdale. "The Child" in Nietzsche: The Man and His Philosophy. New York: Cambridge University, 1999. p. 5 )

${ }^{4}$ Safranski. Op-cit. p.353
} 
mother [he] is still living and becoming old ${ }^{5} . "$ Nietzsche will elaborate on his view of his mother throughout Ecce Homo; condemning her as something very 'German'.' Although in the first instance Nietzsche appears to have grown to recognise and identify with his mother, this identification is better recognised as a form of self-deprecation and distaste.

The antagonistic relationship between mother and son described in Nietzsche's works, however, does not appear exemplary of his everyday experience with his mother. For all the difficulties he had with his motherspecifically, the inability of the mother to understand the son-Nietzsche never failed to write a thank-you letter home upon receipt of packages of sausages and socks $^{7}$. (And, conversely, perhaps it is important to remember that Nietzsche remained a son who required his mother to send packages of socks and sausages.) Nietzsche's view of the mother's role in determining a son's relationships with women in general is given in the aphorism entitled "From the Mother" in Human, All too Human: "Everyone carries within him an image of woman that he gets from his mother; that determines whether he will honour women in general, or despise them, or be generally indifferent to them ${ }^{8}$."

Nietzsche's relationship with his sister Elisabeth was equally fraught with difficulties. She was involved constantly and consistently in her brother's life either at his behest or her own. Like her mother, Elisabeth had difficulty

\footnotetext{
${ }^{5}$ Friedrich Nietzsche. "Why I am so Wise" in Ecce Homo. Trans. and Ed. Walter Kaufmann. New York: Vintage, 1989. Aph. 1.

${ }^{6}$ Nietzsche's constant and consistent reference to the failings of the German people (essentially that they are the decadents par excellence) makes this comment a clearly intended insult. (Nietzsche. "Why I am so Wise" in Ecce Homo. Aph. 3)

${ }^{7}$ Safranski. Op-cit. p. 167.

${ }^{8}$ Nietzsche. Human, All too Human. Trans. Marion Faber and Stephen Lehman. Ed. Marion Faber. Lincoln: Bison, 1996. Aph. 380
} 
understanding the path her brother had chosen. Nietzsche was equally dissatisfied with his sister's life choices, particularly her marriage to Bernhard Förster, a prominent anti-Semite. (Rüdiger Safranski suggests that Nietzsche's description of himself as the anti-anti-Semite is largely a result of his distaste for his sister and brother-in-law ${ }^{9}$.) Elisabeth was also instrumental (or at least regarded by Nietzsche as instrumental) in destroying Nietzsche's relationship with his one love-Lou Salomé.

Elisabeth was horrified upon hearing of Nietzsche's plan to engage in an intellectual ménage á trois with Salomé and Paul Rée (the mutual friend of Nietzsche and Salomé and the catalyst of their relationship) ${ }^{10}$. Whereas Nietzsche was quite taken with Salomé from the first moment, his sister regarded Salomé as a corrupting force within her brother's life, an opinion which was only reinforced by the plan to live á trois. Nietzsche became so attached to the idea of the communal intellectual work-study group that he held onto this idyllic idea long after it became obvious that it was not going to occur. Elisabeth's loathing of Salomé was reinforced by what she believed was the young woman's treacherous treatment of Nietzsche. Elisabeth wrote to Nietzsche that, as opposed to unconditionally supporting him in his absence, Salomé sided and laughed with his detractors. At first Nietzsche protected Lou (and his view of her) from the scathing tongue of his sister. So much venom, however, is certain to eventually poison; and this case is no example to the contrary. Elisabeth Förster-Nietzsche has become infamous with the concomitant rise in her brother's fame, notably for

\footnotetext{
${ }^{9}$ Safranski. Op-Cit. p 338.

${ }^{10}$ Safranski. Op-Cit. pp.250-251.
} 
her manipulation of Nietzsche's works ${ }^{11}$ and Nietzsche himself ${ }^{12}$ following his descent into madness.

On two occasions, to two different women, Nietzsche proposed marriage. In both cases the proposal was not accepted. Nietzsche's first (half-hearted) proposal, to Mathilde Trampedach, occurred after only three meetings. Nietzsche's swift (and unconvincing) declarations of love took Miss Trampedach by surprise. She, unsurprisingly, refused him ${ }^{13}$. The second woman to whom he proposed was the irresistible Lou Salomé ${ }^{14}$. Whereas his proposal to Trampedach was largely a result of familial and friendly pressure to find himself a wife (and, to a degree, the same could be said about Salomé) Nietzsche appeared to be very much taken with the young Russian Lou. It is said that his first words to her were the terribly romantic: "From which stars did we fall to meet each other here ${ }^{15}$ ?" In Lou, Nietzsche met a woman capable of and interested in conversing with him. He was obviously dazzled by her, and she was charmed by him — but not charmed enough to attach herself as wife. Responding to his sister's unflinching diatribe against Salomé, Nietzsche came to see his involvement with Salomé as a game played, with him as pawn, by his friends Paul Rée and Malwida von Meysenberg.

\footnotetext{
${ }^{11}$ We are still trying to differentiate between Elisabeth's editing and Nietzsche's own. She ostensibly removed the majority of Nietzsche's criticisms of her (and her mother) from his work, in addition to attempting to transform Nietzsche into an anti-Semite.

${ }^{12}$ Elisabeth put the generally catatonic Nietzsche on display in her sitting room for paying customers. For the sake of her customers Elisabeth created Nietzsche's insane appearance; for example, dressing the incapacitated philosopher only in flowing white and allowing his moustache to grow to a ridiculous size. These afternoon viewings of Nietzsche usually involved Nietzsche being sat in front of a piano (playing the piano being one of the few skills he maintained) to play for the customers--a trained monkey with his organ grinder. ( Safranski. Op-Cit. p 318.)

${ }^{13}$ Safranski. Op-Cit. p 250.

${ }^{14}$ It seems only fair to refer to Salomé as irresistible; leaving, as she did, a string of broken hearts in her wake. Nietzsche was by no means the only man to fall prey to her charms.

${ }^{15}$ Safranski. Op-Cit. p250-251.
} 
After falling from the stars, Salomé became in Nietzsche's view "this scrawny dirty smelly monkey with...fake breasts ${ }^{16}$..."”

It is accepted that Nietzsche was in love with Salomé regardless of the strength of his protestations during and after the affair. And Salomé was undoubtedly attracted to Nietzsche - although this attraction was tempered by a degree of revulsion. Salomé's attraction to Nietzsche was never going to pass beyond the intellectual into the erotic. For both Salomé and Nietzsche, their relationship was primarily an intellectual seduction. Salomé wanted nothing more from Nietzsche than conversation and debate and Nietzsche would have been satisfied with this even though their intellectual love-affair had engaged his heart. Nietzsche looked back on the affair with Salomé wistfully as time moved him away from it. Salomé became a subject for Nietzsche's nostalgia and this is exemplified by her inclusion in Ecce Homo. Elisabeth's role in the affair held no nostalgia for Nietzsche-he became more disenchanted with her as he reconciled himself with Salomé. Nietzsche's unrequited love affair and his difficulties with his mother and sister have long been cited as reasons for the development of Nietzsche's virulent misogynistic writings.

Nietzsche had friendships with a number of women, the most notable of these female friendships being Nietzsche's relationships with Cosima Wagner ${ }^{17}$

\footnotetext{
${ }^{16}$ Nietzsche. Draft of a letter to Paul Rée's brother which was never sent. (Safranski. Op-cit. p255)

${ }^{17}$ Cosima was the daughter of Franz Liszt. Before her marriage to Richard Wagner she was married to Hans von Bülow, from whom she was divorced in order to marry Wagner. There is some speculation as to the nature of Nietzsche's feelings towards Cosima largely arising out of a series of letters Nietzsche wrote in the first days following his descent into madness. Nietzsche addressed these letters to 'his beloved Ariadne' signing them 'Dionysos' (Nietzsche. 'Letter of January 3, 1889" trans. The Nietzsche Channel. Accessed on-line 12 May 2005. Available at http://www.geocities.com/thenietzschechannel/nilett7.htm.)
} 
and Malwida von Meysenberg. Nietzsche's relationship with Cosima logically ended as Nietzsche distanced himself from her husband Wagner. His relationship with Malwida ended after she accused him of mistreating his old friend Wagner in The Case of Wagner ${ }^{18}$. The importance of Nietzsche's friendships with women arises from the very existence of these friendships. In contradiction to his own writings against woman's possibility of sustaining friendship ${ }^{19}$ Nietzsche appears to have been as much at ease in female company as he was in male, which is to say, not terribly comfortable at all.

Although it is clear that Nietzsche experienced dissatisfaction in the most important relationships he had with women, dissatisfaction coloured all of his relationships regardless of sex. He believed that he was incomprehensible in his own time. Nietzsche's feelings of betrayal stem from his mistaken trust in the ability of his friends to understand him. In defence of his male and female friends, Nietzsche expected to be understood as a trans-valuator of values, a philosopher par excellence. Nietzsche entered into philosophy with the expectation that he would be immediately recognised as one of history's great minds. As he (and his philosophy) matured, Nietzsche became aware that he would live the life of a great philosopher only posthumously. The result of this realisation, however, meant that Nietzsche's need for real companionship went largely unsatisfied. Nietzsche's inability to find kindred free spirits among his

\footnotetext{
${ }^{18}$ Safranski. Op-Cit. p 315.

19 "Are you a slave? Then you cannot be a friend. Are you a tyrant? Than you cannot have friends. All-too-long have a slave and a tyrant been concealed in woman. Therefore woman is not yet capable of friendship: she knows only love." (Nietzsche. "On the Friend" in Thus Spoke Zarathustra. in The Portable Nietzsche. Trans and Ed. Walter Kaufmann. Toronto: Viking, 1976. p. 169)
} 
contemporaries led him to develop relationships with his future readers throughout the course of his works. Explicitly, Nietzsche attempted to begin his posthumous life before he abandoned his temporal self. Given his difficulty making lasting relationships with men, as well as women, we must wonder why this general social unhappiness translated into misogyny in his works, and not misanthropy ${ }^{20}$.

Beyond his personal relationships with women, we must consider the general state of women during Nietzsche's life; and, more specifically, the philosopher's experience of his female contemporaries. Nietzsche's view of women was particularly affected by his experience of the nineteenth century social phenomena known as hysteria. Hysteria was considered to be a neurotic disease which only affected women as it was believed to develop out of uterine dysfunctions ${ }^{21}$. Nineteenth century hysterics were notably of the upper class. Their disease was 'defined' by the symptoms of flightiness, helplessness, naïveté and all-encompassing victimhood. Nietzsche, and the gross majority of his sex, held these women in contempt. (It would have been difficult not to.) Nietzsche also realised, however, that their 'hysteria' was a socially created disease. Women were forced into hysteria by the paradoxical social forces impinging on them and their place in the world. Women prone to hysteria were kept sheltered,

\footnotetext{
${ }^{20}$ One could argue that popular culture characterises Nietzsche as both misogynist and misanthrope. This is the result of an unfortunate and acute misunderstanding concerning the nature of Nietzsche's work. This misunderstanding is perpetuated by misplaced quotes and continual recourse to Nazi Germany's abuse of the philosopher and his work.

${ }^{21}$ Hystera is the latin word for uterus (Online Etymology Dictionary. "Hysterical" Nov. 2001. Accessed on 23 May 2005. Available at http://www.etymonline.com/index.php?search=hysterical\&searchmode=none.)
} 
naïve, bored, and useless. Nietzsche's contempt for them was tempered by no small amount of pity.

On the opposite side of the social scale we encounter the early proponents of sexual equality. Nietzsche's distaste for these women (he singles out George Sand, Madame de Staël, Madame Roland ${ }^{22}$ ) grates on our modern sensibilities. Although Nietzsche himself was a supporter of allowing women into the universities $^{23}$, he saved particular virulence for his attacks on women who preached female equality. Nietzsche's dislike of these women (and men, for that matter) is consistent with his philosophical analysis on the dangers of equality. Nietzsche was no more a democrat than he was a first-wave feminist.

It is common for scholars to dismiss Nietzsche's writings on women as the product of a man foiled in love and therefore vengeful against women. Many students of philosophy are quickly taught to simply ignore Nietzsche's writings on women. We must ask ourselves whether or not this is a correct assessment. Nietzsche's aphorisms on women read as unenlightened. They are petty, prejudicial bites from insignificant flies. The sheer number of Nietzsche's bilious comments on women is perhaps their most significant aspect. For the philosopher who described his greatest goal as the overcoming of revenge, the corpus of his

\footnotetext{
${ }^{22}$ These three women are mentioned by name in aphorism 233 in the section entitled 'Our Virtues' in Beyond Good and Evil. George Sand receives further treatment at Nietzsche's hands in aphorisms 1 and 6 of 'Roving Expeditions of an inopportune philosopher' in Twilight of the Idols. ${ }^{23} \mathrm{He}$ voted in favour of allowing women into the doctoral program at the University of Basel, where he was a professor. (Safranski. Op-Cit. p 361)
} 
writings on women reveals him as nothing but a vengeful spirit. By agreeing with this judgement we reach an end and find ourselves in accord with many of Nietzsche's criticisers ${ }^{24}$. The satisfaction of arriving at this judgement is overshadowed, however, by the hanging question of 'why?' Why did Nietzsche write so many aphorisms concerning women-both mytho-allegorical representations of women, and descriptions of woman-as-such? What is Nietzsche saying when he speaks women? What is woman for Nietzsche? In order to further address this question let us turn to Nietzsche's explicit writings on women. What we first realise is that the philosopher's gynocentric aphorisms can be separated into two broad categories: mytho-allegorical representations and observations on woman-as-such.

Nietzsche uses female mytho-allegorical interpretations in a number of his works (the prologue to Beyond Good and Evil with its characterization of truth as woman is one example, although these feminised concepts are predominantly found in Thus Spoke Zarathustra.) The mytho-allegorical characters in Thus Spoke Zarathustra are used to define the greatest desires of humanity (although heretofore limited to men); hence the personification of Zarathustra's Wild Wisdom and his love affair with Life. Nietzsche's use of mytho-allegorical representations is directly in accordance with his self-prescribed task of writing a new mythology for humankind. These characterizations are, therefore, highly idealised. Here we have the most 'perfect' women in that they are absolute conceptual definitions. For example 'wild wisdom' is everything her name

${ }^{24}$ Martin Heidegger spearheaded this largely undeniable criticism of Nietzsche's philosophy. (Heidegger. Nietzsche: Volumes One and Two. Trans. David Ferrell Krell. San Francisco: Harper Collins, 1979-1987) 
conjures-a storm which envelopes Zarathustra, a horse which must be tamed. She is Zarathustra's wisdom and so characterises philosophy's general definition of wisdom as something that belongs to us and is yet separate from us, something which needs to be controlled by our reasoning powers and harnessed to do the work which we require of it, while remaining far enough outside of our power to be actual wisdom and not mere opinion. But these mytho-allegoric women are also perfect in their femininity. Continuing with the example furnished by "wild wisdom;' having succumbed to Zarathustra's 'lightning bolt,' she gives birth to Zarathustra's 'children.' The competition between accepting these women as concepts versus accepting them as women leaves us in a confused position. How are we meant to interpret Nietzsche's mytho-allegorical representations?

It is common to not consider Nietzsche's mytho-allegorical female representations as part of his teaching on women. We are expected to accept them only as personified concepts; examples of Nietzsche's poetic philosophic style, i.e. the importance of Wild Wisdom is not associated with her female characteristics but her personification of wisdom. The question we must ask ourselves is why the concept needs to be separated from its female representation. Or, would the concept remain the same if separated from its female representation? If we answer 'no' to this second question Nietzsche's mythoallegoric women become reminiscent of the goddesses of antiquity ${ }^{25}$. Like the goddesses, these women embody a specific concept (i.e. wisdom) and their embodiment of this concept is tied to their existence as a being. Take, for

\footnotetext{
${ }^{25}$ Is it not possible that answers of 'yes' only arise out of a lack of 'fit' between these characterizations and Nietzsche's reputation as a misogynist?
} 
example, Aphrodite, the Greek goddess of love. She defines all forms of love through her position and role as goddess of love.

We have already considered the meeting of concept and representation in our examination of the moments of the opening line to the prologue of Beyond Good and Evil wherein we came to the conclusion that the connection between concept and representation is integral to an understanding of Nietzsche's philosophy. Nietzsche is a mythmaker and he wants his readership to associate Wild Wisdom with the search for wisdom. Arguably, she is Nietzsche's new Minerva. We should be able to fall in love with his mytho-allegorical representations not only because of what they are, but also because of who they are. This call to love, in concert with our inability to separate woman from concept, returns us, however, to the difficulty we first encountered with regard to Nietzsche's relationship with women. Regardless of our understanding of Nietzsche's conceptual definitions, how can we accept his use of feminine representations given his difficulty with women? How can we 'believe' in this new mythology if we cannot accept Nietzsche's understanding of woman?

Having not found our answer in either Nietzsche's life, or in his elaborate creation of mytho-allegoric woman we must turn to his descriptions of woman-assuch. All of Nietzsche's major works (excepting The Birth of Tragedy) contain a sizable selection of aphorisms dedicated directly to the nature of woman-as-such. This alone separates Nietzsche from the majority of male philosophers, many of whom never deigned to include a discussion of woman among the lofty ideals they associated with men. This is not to suggest that Nietzsche's aphorisms 
concerning women were meant to attract women to his philosophy; rather, it appears very much to be the opposite. Firstly, as we have mentioned previously, these aphorisms resound with petty spite-making them largely uninviting to a female readership. (Consider: "Woman has so much reason for shame; in woman there is concealed so much pedanticism, superficiality, schoolmarmishness, petty presumption, petty unbridledness and petty immodesty... which has fundamentally been most effectively controlled and repressed by fear of $\operatorname{man}^{26}$.") Secondly, as Nietzsche himself states, one should never speak of woman-as-such to woman ${ }^{27}$. All that he has written on women, therefore, is explicitly directed at and concerned with a male readership.

Let us consider aphorism 68, 'Will and Willingness' in Book Two of The Gay Science in the hopes of gaining some insight into Nietzsche's view on woman and thus allowing us to come to terms with the discord created by his general consideration of women. Our use of The Gay Science is justified given the number of aphorisms concerning women (fifteen) and their general virulence in tone. Aphorism 68 (full quote below) is interesting for our purposes because Nietzsche appears to attempt to come to terms with his conception of woman within it:

Will and Willingness.-Someone took a youth to a sage and said: "Look, he is being corrupted by women." The sage shook his head and smiled. "It is men," said he, "that corrupt women: and all the failings of women should be atoned for and improved in men. For it is man who creates for himself the image of women, and women who forms herself according to this image."

"You are too kindhearted about women," said one of those present; "you do not know them." The sage replied: "Will is the manner of men; willingness that of women. That is the law of the sexes-truly a hard law for women. All of humanity is innocent of

\footnotetext{
${ }^{26}$ Nietzsche. Beyond Good and Evil. Aph. 232

${ }^{27}$ This is exemplified in both the full text of Aphorism 232 in Beyond Good and Evil and, more specifically, "On little old and young women" in Thus Spoke Zarathustra.
} 
its existence; but women are doubly innocent. Who could have oil and kindness enough for them?"

"Damn oil! Damn kindness!" someone else shouted out of the crowd; "women need to be educated better!"- "Men need to be educated better," said the sage and beckoned to the youth to follow him.-The youth, however, did not follow him ${ }^{28}$.

We are faced with the suggestion here that it is man, rather than woman, who creates the image of woman. She merely forms herself around this image. What does this mean? Nietzsche's choice of words suggests that man is responsible for creating the 'image' of women. This word 'image' implies that what one sees of woman is not in fact what woman is. This amorphous consideration of woman is consistent with Nietzsche's assertion that every woman is a wearer of masks or veils. Even more intriguing is the suggestion that woman is not responsible for the veil she wears. In this we are provided with an explanation as to why Nietzsche specifies that one should only speak of womanas-such to men. If men create the image of woman (and women, in general, conform to this image), then in order to change/effect woman one must address men. The realisation of this colours all interpretations of Nietzsche's writing on women. Nietzsche is not a simple misogynist (if we can call him one at all) given that his critique of woman is directed at men. Nietzsche's philosophical hatred of woman is a result of his revulsion at the sight of woman as she is created by man. Nietzsche's criticism of woman is more a criticism of the creative (imposing) male than it is of the adorned woman. In suggesting this Nietzsche's work

\footnotetext{
${ }^{28}$ Nietzsche. The Gay Science. Trans. and Ed. Walter Kaufmann. New York: Vintage, 1974.
} 
anticipates the ideas of Simone de Beauvoir, who, in her seminal work The Second Sex, also considers the non-existence of the female gender ${ }^{29}$.

Also of interest and importance in this passage is the concept of the will as it is characterised by the discussion of will versus willingness. A clear reference to his doctrine of the will to power, the suggestion is that the formation of the female gender occurs as a result of man's will-to-power. Woman has the difficult task of suspending her own will-to-power to 'fit' the description defined for her by men. Or, rather, woman must manipulate her will-to-power in order to facilitate man's willing. She must transform her own will-to-power into passivity. Woman is doubly innocent of her existence because she has no part in its creation-she fills the role designed for her. Woman is-since the death of God-man's greatest artwork. This artistic achievement is all the more successful in light of the fact that man does not consider himself the artist of woman. Man as artist believes that the outward display of femininity he has created for woman is the actual face of the female sex. Nietzsche's criticism of woman-as-such is therefore in keeping with the task of trans-valuation of all values. The 'value' known as woman must undergo trans-valuation in order to ring true.

The notion of woman as art is a 'simple' answer to the question of our first question: 'how are we to accept Nietzsche's notion of woman?' With this answer we receive only an outline of the full story of who/what woman is for Nietzsche. It is an insufficient answer in general, although it shall, for the moment, suffice.

\footnotetext{
${ }^{29}$ This idea has also been considered by Lynne Tirrell in her essay "Sexual Dualism and Women's Self-Creation: On the Advantages and Disadvantages of Reading Nietzsche for Feminists" published in Nietzsche and the Feminine. Ed. Peter J. Burgard. Virginia: University Press of Virginia, 1994. pp158-182)
} 
Let us now turn our attention to the second problem we encountered in our exegesis of the statement 'suppose truth is a woman-What?'; namely, 'What is Nietzsche's truth ?'

Truth is the most elusive of ..., of what? What is truth? Is it a concept? Is it a thing? Is it an idea? Is it a reality? When we search for truth we always feel as though we are grasping the air in the place where it last was. Truth is most often described by meaningless tautologies - 'truth is true'-or 'magical' metaphors. Yet regardless of the difficulty we encounter-and have always encountered-when we search for truth, we place monumental value on what we believe to be the 'Truth'. We have developed many paths to truth and call each new one more truthful than the ones that came before. Such is the case with science-our present greatest will-to-truth. With science, as with religion previously, we believe that we now grasp truth - that it 'truly, true, truth' has been discovered. In opposition to other philosophical endeavours Nietzsche begins his examination of truth, as a 'why?' rather than an expectation or a good. He questions our urge to truth; "granted we want truth-why not rather untruth ${ }^{30}$ ?"

It is one of the 'prejudices of philosophers ${ }^{31}$, to promote the will-to-truth over the will to untruth, according to Nietzsche. Is it possible that truth, and our ongoing search for it, is nothing more than a left-over predilection? Nietzsche calls on us to question the philosophical (religious/scientific) assumption that truth is the light which illuminates the greatest 'good.' He would not have us accept the opinion that truth provides insight into the a priori. Truth, to

\footnotetext{
${ }^{30}$ Nietzsche. "On the Prejudices of Philosophers" Beyond Good and Evil. aph 1. Emphasis Nietzsche's own.

${ }^{31}$ Nietzsche. "On the Prejudices of Philosophers" Beyond Good and Evil. aph 1-23.
} 
Nietzsche, is therefore nothing more than a believable lie we have created and told to ourselves. If truth is an opinion it can never be ultimate, but is always be contingent. Moreover, viewed in this way truth is of limited significance. The significance of truth belongs only to its creator, as a work of art is significant to the artist. An outsider's interest in truth is therefore a misplaced interest in the truth maker, it cannot function as an interest in the truth itself. Truth is still 'important', but its importance lies in its value to the individual creator, and the 'success' of its believability. This view of truth means that Nietzsche does not spend his philosophical time looking for truth, but is rather occupied with questioning the will-to-truth.

Why does man place such high value on truth? Why do we spend such an inordinate amount of time-effectively our entire lives - searching for the 'Truth?' Nietzsche's answer concerns the most successful definition of truth to date-Christianity. Christianity took as its highest good the will-to-truth which it defined as the will to God. The radical success of Christianity and the will to God lies in man's need to find an answer to the causae primae of the world and the justification of his own existence. Christianity and the will to God provided answers to both of these questions: God and eternal salvation. These answers were sufficient and satisfactory to humankind for two thousand years. However, the progression of time saw man develop new ways of looking for the primary cause of the world and existential justification; i.e. science. The answers of God and eternal salvation no longer seem to fit with the question asked. In this way, Christianity became its own gravedigger. The will-to-truth as a highest good 
exploded the very concept it sought to find-God. This is why Nietzsche claims that man is the murderer of God.

We must not, however, make the assumption that truth and the will-totruth are unimportant for Nietzsche, because the opposite is correct. The Christian will-to-truth created a goal for mankind in eternal salvation. With the ultimate demise of God, man has lost this goal and anchor. Rather than actively engaging in self-overcoming, man stagnates in nihilism. The provision of this goal is the single greatest achievement of the Christian mythology. Nietzsche has taken it upon himself as his ultimate task to provide mankind with another goal: this is his trans-valuation of all values.

Because man is incapable of surviving the most terrible truth of his existence, his own mortality, and yet must live each day aware of it, Nietzsche advocates the development of new myths. Myths become for Nietzsche the veil/mask which cloaks the terribleness of life. It is therefore untruth which saves $\operatorname{man}^{32}$. Untruth, although appearing hypocritical, becomes the driving force behind the will-to-truth. Truth, as it relates to myth development, becomes the creative development of all that is life preserving.

Let us return to where we began. Having ascertained that, for Nietzsche, the concepts of truth and woman are in constant conversation with one another, we ran into the difficulty of accepting Nietzsche's misogynistic writings on women and understanding his use of truth. In answer to the first question we

${ }^{32}$ The life saving noble lie has a history as old as the western philosophical tradition, with one of the best examples coming from Plato's Republic. (Plato. Republic. Trans. G.M.A Grube. Ed. C.D.C. Reeve. Indianapolis: Hackett, 1992. 414a-417b.) 
arrived at the suggestion that Nietzsche cannot be simply described as misogynistic. Rather he does not believe that woman is who man says she is. Or, woman, meaning the female gender, does not 'exist' for Nietzsche because the feminine is a mere construct of the masculine. In answer to the second question we came to the conclusion that truth for Nietzsche is creative and unstable. The relationship between these two concepts has been further demonstrated by our answers to these two objections. Having believed that we delayed our beginning we have in fact well begun our journey.

In overcoming our reservations to the relationship between the concepts of 'truth' and 'woman' we have made our task more intricate. The simple answer we provided for the first objection -our acceptance of Nietzsche's use of woman-will not suffice for our greater task. We must begin our journey therefore by providing an in-depth analysis of the suggestion that the present female gender is an existential lie for Nietzsche-that 'woman' is art. This suggestion has far-reaching ramifications on the concept of 'truth' which we shall examine following greater development of this primary supposition. 


\section{Chapter One \\ The prehistory of gender}

We have begun our journey into the elaboration of the relationship of 'woman' and 'truth' in Nietzsche's works by making what would seem to be a preposterous claim; namely, that 'true' female gender does not exist for this philosopher. Because this claim seems so suspicious we must investigate it further before continuing. In fact we must take a few steps back, for we have left our 'bags' unpacked and are unprepared to continue any further. We came to consider the intangibility of woman by examining Nietzsche's elaborations on both mytho-allegorical female representations and 'woman-as-such'; but this is not the root of the assertion that the female gender is non-existent for Nietzsche. In order to fully elaborate this suggestion and thereby remove any niggling questions which may arise from it we must reach the radix of the supposition within the greater context of Nietzsche's thought. If we cannot justify our suggestion through this method it must be negated.

Before we begin we must better define the word 'gender'. Although 'gender' was initially developed in order to denote biological sexual definition it 
has evolved to reflect a much more complex understanding of human categorization. We understand gender to refer to a series of characteristics loosely based on assumptions of the substance of 'femininity' and 'masculinity.' These characteristics of 'masculinity' and 'femininity' have been attributed as such because of the conjecture that men cultivate characteristics which are explicitly 'masculine' whereas women cultivate explicitly 'feminine' characteristics. These gender characteristics, which theoretically develop out of biological sexuality, are then said to define what a 'man' is or what a 'woman' is ${ }^{33}$. A 'man' must not only possess a penis but be readily identifiable by masculine gender characteristics; without the presence of both there is no 'man' as such. Subsequently, 'woman' is not only in 'possession ${ }^{34}$, of a vagina but is identifiable by her feminine characteristics ${ }^{35}$. The movement from mere biological definition to a broader, more complex and yet more amorphous definition of gender comes as a natural result of the 'deepening' of language through linguistic evolution. As it was (theoretically) observed that men behaved in a certain way and women behaved in another, it has been accepted that these behaviours are incontrovertible characteristics of each of the sexes. Different behaviour in the sexes came to denote aspects of each beyond the biological. The

\footnotetext{
${ }^{33}$ The concept of gender was finally recognised as significantly more difficult than our two gendered world admits with such works as Judith Butler's work Gender Trouble. The simple categorization of masculine equal heterosexual male and feminine equals heterosexual female does not account for a number of groups within our society: such as homosexual men and women and trans-gendered individuals.

${ }^{34}$ Whether or not the vagina has in fact been treated as a 'possession' as opposed to the lack of a possession (as Freud would have it) is a point of contention in the works of a number of feminist theorists. Luce Irigaray is particularly well known for taking up the cause of the vagina as possession.

${ }^{35}$ Consider the quote from Simone de Beauvoir 'It would appear, then, that every female human being is not necessarily a woman; to be so she must share in that mysterious and threatened reality known as femininity.' (Beauvior. 'Introduction' in The Second Sex. Trans. and Ed. H.M.

Parshley. New York: Alfred A. Knopf, 1971. p xiii.)
} 
broadening of gender definition to include behavioural characteristics also arises out of the mythologization of each of the sexes. Take, for example, the bible wherein men and women are given different specific roles as based on how they behave ${ }^{36}$. The argument is then made that these roles, because of their characteristics, cannot be transferred to the opposite sex. Gender is, therefore, in Nietzschean language, a value; meaning that the masculine characteristics which embody the male gender are values by which we define a 'man' and vice versa. Gender characteristics are no longer tied explicitly to the biological reality of men and women but develop as a linguistic function of that biological reality. Gendered language grows with the abstraction of language to refer to concepts in addition to biological realities. Given this, gender definitions become as integral to human communication as they are to categorization.

Through out the course of this thesis I will use the words 'fe/male gender' and 'feminine/ masculine' interchangeably and as separate from the purely biological categorization of sex. Although there are arguably nuances associated with each of the words both of them clearly articulate the concept of gender, and the nuances peculiar to each one provide further insight into the totality of the concept. Fe/male gender is more explicitly linked to the original biological definition of the sexes and, therefore, use of it suggests the conferral of scientific truths. Feminine/masculine bears the marks of the linguistic broadening and deepening of the concept of gender and thus appears to denote a more inchoate conception of the sexes.

\footnotetext{
${ }^{36}$ New Revised Standard Version: Catholic edition, Gen. 2-4.25
} 
If gender is a value for Nietzsche then we must be able to locate gender definition within Nietzsche's discourse on values. To begin we must understand what a value is for Nietzsche. Through recourse to our values we categorise the world. Every thing/person/action etc. we come into contact with is assigned a value, and this value dictates how we will respond to every thing/person/action etc. Consider, for example, Nietzsche's elaboration of truth as we have already addressed it. We have stated that the nature of truth, for Nietzsche, is untruth. But this is unimportant aside from the value which we ascribe to each of the concepts. Truth is valued, untruth is not and this assignation of value is what drives Nietzsche's examination of truth. Thus values are of ultimate importance to Nietzsche - through them we interact with each other and the world.

Within his consideration of values Nietzsche allocates prime importance to the revolution of values. This is owing to his belief that it is through the movement of values that humanity is given its goal-the goal of self-overcoming. Values give humanity a goal by recourse to our emotional (thoroughly irrational) response to them. What we value is considered good for us, what we do not value is defamed as bad. For example, by placing value on the will-to-truth man discovered science. By valuing science man came to 'murder' God and thus lost the driving value which created the rational scientific process in the first place. When a value system fails to promote self-overcoming in humanity, the values themselves must be re-valued in order to provide a new goal. If values are not revalued and a new goal not posited, humanity undergoes 'spiritual $\mathrm{crisis}^{37}$.' 
Spiritual crisis is understood by Nietzsche to be the sapping of 'value' from that which we have denoted as 'good' while maintaining in the belief the 'good' as a 'good.' We, therefore, make the 'good' meaningless, it becomes empty and unbelievable. If we cannot provide ourselves with a justification as to why we value our 'goods' then we see no reason to value them. In this instance the 'good' has changed although the criterion for valuation has not. In a time of spiritual crisis hollow values remain 'goods,' stripping the world of meaning for us. A meaningless world is characterised by an encounter between the will-to-truth and the noble lie. The disparity between the two breeds the social black hole known as nihilism. We become nihilists in Nietzsche's definition of the word, 'What does nihilism mean? That the highest values devaluate themselves. The aim is lacking; 'why?' finds no answer ${ }^{38}$,' Our modern period has been diagnosed by the philosopher as wallowing in nihilism-and ours is nihilism of the crudest sort. $^{39}$ Nietzsche has made it his particular task to examine and re-value (in his words, trans-value) human values in order to give humanity a new goal and thus overcome the crisis of nihilism.

Nietzsche posits that values change through revolutions which are propelled by a concept he refers to as the will-to-power. According to Nietzsche

and Planetary Rule" in Faith, Reason, and Political Life Today. Eds. Peter Lawler and Dale McConkey. New York: Lexington Books, 2001. p35.)

${ }^{38}$ Nietzsche. 'Principles of a New Evaluation' in The Will to Power. Ed. and Trans. Walter Kaufmann and R.J. Hollingdale. New York: Vintage, 1968. Aph. 2.

${ }^{39}$ Nihilism presently manifests itself in society through decadence. The current construction of nihilism as decadence became apparent to Nietzsche through movements such as 'art for art's sake,' and various other disconnected absurdities. The results of humanity's decadent nihilism is cringingly depicted in Nietzsche's illustration of the 'last men' in Thus Spoke Zarathustra. (Nietzsche. 'Zarathustra's Prologue -5' in Thus Spoke Zarathustra. pp128-131) Nietzsche's clear distaste for our decadent nihilism is prominently displayed in aphorisms 208 and 254 of Beyond Good and Evil. 
there has only been one value revolution in humanity's history thus far-the slave revolt in morality. The value legislation instituted by the slave revolt in humanity was hugely successful. Some two thousand years on we still largely exist under the value system instituted by this revolt. It is the incapability of the value legislation imported by the slave revolt in morality to sustain viable goals for humanity which has placed modernity in its current state of nihilism. Given this, let us examine Nietzsche's notion of the development of values.

We must begin with a definition of Nietzsche's concept of the will-topower as it drives Nietzsche's explanation of the development of values. Nietzsche's will-to-power closely resembles the ancient concept of pleonexia. This drive-the drive to dominate, to exert power over everything-exists in all humanity. It is the insatiable lust for power, the strength of which is such that, according to Nietzsche, we would rather will our own nothingness than not will at all $^{40}$. Nietzsche claims that every action is predicated on the will-to-power; even the 'will-to-power' is will-to-power ${ }^{41}$. The driving force of humanity is encapsulated by the will-to-power, and we act only as a result of this force. It is a scientific force characterised by the transfer of energy and it is an 'instinct' (a biological drive). We cannot escape from the will-to-power while we live as the will-to-power is a characteristic of life. Rather the will-to-power simply is. As Nietzsche describes it: 'the will to power is not a being, not a becoming, but a

\footnotetext{
${ }^{40}$ Nietzsche. 'What is the Meaning of Ascetic Ideals?' in The Genealogy of Morals. Aph 14.

${ }^{41}$ Nietzsche. 'On Self Overcoming' in Thus Spoke Zarathustra. pp. 225-228.
} 
pathos - the most elemental fact from which a becoming and effecting first emerge $^{42}-$

In Nietzsche's psychohistory The Genealogy of Morals the development of values occurs in two linked moralities: master morality and slave morality. Master morality develops first although it is contingent on the presence of the slave. (As Hegelian logic predicates there can be no master if there is no slave to recognise him as such.) The master asserts his mastery-and actualises his willto-power-through the lordly right of naming ${ }^{43}$. Through naming the master develops the values of his morality: 'good' and 'bad.' The master names as 'good' all things which relate to himself (strong, noble, proud etc.); whereas he names 'bad' what is outside of his purview. The slave-who is bound to, but outside of, the master-is named 'other' and is, therefore, 'bad.'

From his position of weakness, the slave develops slave morality. This, too, is an act of the will-to-power as it is the slave's goal to become master. Slave morality, born from the depths of ressentiment, is the embittered slave's actualization of his vitriolic antipathy for the master. In the shadow of the master the slave is forced to become 'clever' and creative. The slave inverts the 'good/bad' value dichotomy of master morality, and takes for his values 'good' and 'evil'. Slave morality intellectualises master morality's 'bad' (slavish

\footnotetext{
${ }^{42}$ Nietzsche. 'Principles of a New Evaluation' in The Will to Power. Aph. 635.

${ }^{43}$ Nietzsche. 'What is Noble' in Beyond Good and Evil. Aph. 260.
} 
characteristics) in order to develop the slavish 'good' and vice versa. This inversion and intellectualization is clearly described by the following passage from Nietzsche's Genealogy:

That lambs dislike great birds of prey does not seem strange: only it gives no grounds for reproaching birds of prey for bearing off little lambs. And if the lambs say among themselves: 'these birds of prey are evil; and whoever is least like a bird of prey, but rather its opposite, a lamb-would he not be good?' there is no reason to find fault with this institution of an ideal, except perhaps that the birds of prey might view it a little ironically and say: 'we don't dislike them at all, these good little lambs; we even love them: nothing is more tasty than a tender lamb ${ }^{44}$.

What we come to realise is that Nietzsche's slave revolt in morality is effectively a fight over the use and meaning of language ${ }^{45}$. Language first developed under the master who exercised his will-to-power by according value through language definition. The master's use of language, however, is simple at best. Masterly language is simplistic because, according to the right of the master, the subject and object correspond absolutely with the words chosen to define them. The master, as subject, is noble and there is no definition or use for the word noble beyond the master who defines it. The slave, as object, is base because he is not the subject and this baseness corresponds absolutely with the slave's objectivity. With the slave revolt in morality language becomes abstract. The slave trans-values the language of the master. If we examine the given case of 'master equals noble,' we find that the slave has transliterated the masterly definition of 'noble=strength' into slave morality, thus making it base. To complete this trans-valuation the slave confers the valued nobility onto himself,

\footnotetext{
${ }^{44}$ Although the final lines of this quote suggest affection on the part of the master's for the slave's (the birds of prey for the lambs) this is only in keeping with the master's 'appreciation' of the slaver for ensuring that the master is master. (Nietzsche. "'Good and Evil,' 'Good and Bad"' in Genealogy of Morals. Trans and Ed. Walter Kaufman. New York: Vintage, 1989. Aph. 13.) ${ }^{45}$ Nietzsche. The Gay Science. Trans and Ed. Walter Kaufmann. New York: Vintage, 1974. Aph. 58.
} 
claiming that it is his weakness which makes him 'noble.' The slave, similar to the master before him, regards himself as noble because he is all that the master is not. Therefore, the slave-through an act of the creative will-to-power, transforms subject into object, adopting the words of the subject but intellectualizing their meaning. Simple masterly language, wherein the object/subject is equal to the concept (or word) becomes intricate with the slave's justification of his own subjectivity.

The inevitable clash between master morality and slave morality led to the downfall of the masters through the slave revolt in morality. The simple linguistic definitions of the master were no match for the slave's abstraction of language. This, in itself, is not a problem for Nietzsche. In fact the slave revolt in morality, with its development of the intellect, pushed humanity to greater heights of development. The simplicity of masterly language, if left unchallenged, would have resulted in stagnation. Because the master names things as they 'are' there can be no change. And because there is no change there can be no improvement and, therefore, no goal. According to the master 'all is as it should be'-change is inconceivable and impossible. If it were not for the success of the slave revolt in morality humanity qua humanity would not exist ${ }^{46}$.

As we have said before masterly values are 'good' and 'bad.' These values correspond directly to the simple linguistic definitions of the master. Master equals good and master equals noble, therefore good equals noble; or, in

\footnotetext{
${ }^{46}$ Mankind defines itself as the creature in possession of self-consciousness, a characteristic which is inevitably missing in the master who is incapable of recognizing himself as both subject and object. Inability to separate himself into subject and object results in the master having simple (subjective) consciousness
} 
other words, at all times there is no further information in the concept than there is provided in the subject. With the inversion of values in the slave revolt; slave equals good and slave equals noble, but these designations of goodness and nobility require a caveat and an explanation in order to become true. A caveat is required because master morality depicts and defines the 'natural' order of the universe: the slave seeks to change this order. The slave defines himself as good because he is weak, and the 'good' in this weakness is defined by the characteristics of '...pity, the kind and helping hand, the warm heart, patience, industriousness, humility, [and] friendliness ${ }^{47}$. But the transformation of these 'weak' characteristics into 'ruling' characteristics—given that, 'the weaker should serve the stronger ${ }^{48}$, - can only be justified through the creation of an outside master. Therefore slave morality creates a new master and names him 'God.'

The creation of the conjecture 'God' justifies the slave's 'weak' characteristics as 'good' because 'God' is the last vestige of master morality. 'God' is endowed by his creator with the ability to name and, therefore, designate value. The values 'God' designates are, unsurprisingly, defined by the 'good/evil' dichotomy of the creative slave. (We have only to remember the biblical story of Genesis in which 'God' creates and proclaims his creation as 'good' in order to assert this.) Moreover, with the development of 'God' the slave transforms the human totality (multiplicity) to accord himself some small share of his 'God,' and, therefore, align himself with ultimate mastery. The slave bifurcates our totality (multiplicity) into base/evil body and 'Godlike'/good soul. Thus the

\footnotetext{
${ }^{47}$ Nietzsche. 'What is Noble?' in Beyond Good and Evil. Aph. 260.

${ }^{48}$ Nietzsche. 'On Self-Overcoming' In Thus Spoke Zarathustra: Second Part. p 226.
} 
success of the slave revolt in morality is intimately linked with the JudaeoChristian tradition ${ }^{49}$.

But what has all this to do with Nietzsche's view on the female gender? Let us begin by considering her role under master morality. Master morality's understanding of language cannot lead to gender definition or valuation in any useful way. Master morality only allows for the simple recognition of difference. Under master morality all that can be said with regards to gender is woman does not equal man, and man does not equal woman. This recognition cannot be explicit in its allotment of value to either of the sexes because value designation is entirely the prerogative of the subject. As we cannot distinguish the sex of the subject under master morality's linguistic categorization we cannot make a value judgement. Although Nietzsche recognises master morality as being explicitly masculine there is nothing substantial within his own writings to support this, and we must therefore regard it as bias ${ }^{50}$. What is clear, in any case, is that gender, as a value-laden linguistic categorization, cannot develop under master morality. We must therefore turn to master morality's inversion as a result of the slave revolt in morality.

What happens to 'woman' as we undergo the slave revolt in morality? The primary aim of the slave revolt is the inversion of masterly values through the redefinition of words. Our first step in answering this question would thus be to

\footnotetext{
${ }^{49}$ Nietzsche asserts that the slave revolt began with the Jews (Aph. 195 in Beyond Good and Evil) and was affirmed through Platonism and Christianity.

${ }^{50}$ In order to define master morality as masculine Nietzsche needs to make use of abstract gender designations which are logically unavailable to the naïve master as the philosopher defines him.
} 
distinguish the values accorded to man and woman under master morality. As we stated above, however, master morality cannot justifiably attribute man or woman with value. We must therefore make a conjecture and accept Nietzsche's bias that master morality is masculine. Under this conjecture, value is clearly separated between woman and man and master morality emerges as the starting point in the development of gender values. These gender values are formulated as such: man is not equal to woman and man (as subject) equals good, therefore, woman (as object) equals bad. We would expect the slave's trans-valuation of values to transform this dichotomy but, according to Nietzsche, it does not. Nietzsche's reasoning behind woman's static position in the slave's trans-valuation of values leads us directly to our primary assertion that the female gender does not exist for Nietzsche.

The first reason why Nietzsche does not regard the slave revolt in morality as trans-valuing the value accorded to the feminine is that Nietzsche considers the slave masculine in addition to the master. The slave revolt in morality thus occurs when male slaves overthrow their male masters. Woman is effectively barred from partaking in the slave revolt. Why? We find the answer in the drive of the will-to-power. The master, who we have accepted on Nietzsche's behalf as masculine, acts on his will-to-power by relegating women and weak men to the position of other. The body of slaves who feel the sting of the master's domination are therefore biologically male and female. But even in slavery there is the lust to dominate, and the male slaves enact their will-to-power by asserting their superiority over their female counterparts. Woman thus becomes the 
ultimate other, the supreme object. When the male slaves foment successful revolt through the trans-valuation of values, it is their will-to-power which drives their domination of their previous master. But having placed themselves at the 'theoretical' apex of human development by making themselves master, the slave is not inclined to reach into the depths and pull the lowliest human-woman-up to the heights. After all, even in slavery a male was at least better than a female. ('Thank you God...for not making me a woman ${ }^{51}$.') Woman is so 'obviously' 'other' to man that 'as a matter of course' she remains an object under slave morality.

The second reason, which logically partakes in the first, brings us back to Nietzsche's assertion that man creates the image of woman ${ }^{52}$. The success of the slave revolt places the newly powerful slave in a position to affirm or reject the conjecture that 'woman' is other. The slave, acting in accordance with his willto-power, maintains her as other. But, in her otherness she is abstracted and intellectualised by the slave-she is, as we first defined her, a work of art; this is how man 'creates' the image of woman. A mere objective creation can not logically participate in the fight between subjects. Having asserted this we come part way to placing woman within the context of Nietzsche's greater philosophical undertaking. Our final task, in order to absolutely justify our initial proposition, is to elaborate our original simplistic definition of woman as art. We must understand the 'value' accorded to her as artistic representation.

\footnotetext{
${ }^{51}$ My own paraphrase of the Jewish Birkot Hashachar.

${ }^{52}$ Introduction, p. 16.
} 
What does the artistic image of woman look like? She looks like the perfect representation of the slave's 'good'-she is a mirror in which he is reflected back on himself. The slave must value 'woman' as a good because of his complex visceral reactions to her. He is repulsed by her 'otherness' with his Godlike/masterly 'soul,' but he desires this same otherness with his human/slavish body. Woman must be draped with the veils of the slave's 'good' in order to justify his desire for her, and she must wear a series of masks in order to cap her own subjecthood. In cloaking and covering 'woman' so completely with paint from his paint-box the artist/slave mythologizes his creation. He makes her desirable to him, but ensures that the representation is 'flawed' to guard against being overcome by her. Woman has become a value-laden gender description, but the gender she is dressed in is not her own, it is a watery reflection of the creative slave.

This is a perversion of woman. She is perverted by the imposition of gender because it does not describe who she is-it perverts her reality. She is not and never herself, and thus she becomes an explicit example of Nietzsche's theory of the 'bad conscience ${ }^{53}$ ', Developed out of slave morality's separation of the human multiplicity into body and soul, the bad conscience is a direct result of the slave's repression of the body and bodily desires. By outlawing these desires the slave does not 'kill' them but pushes them 'underground' where they fester like an unattended wound ${ }^{54}$. Guilt and shame are both manifestations of the bad conscience. Woman, because of the opposing responses she produces in men,

\footnotetext{
${ }^{53}$ Nietzsche. "Second Essay, Section 4" Genealogy of Morals. Trans. Walter Kaufmann and R.J. Hollingdale and Ed. Walter Kaufmann. Vintage: Toronto, 1989. pp 62-63.

${ }^{54}$ Nietzsche. "Second Essay, Section 7" Genealogy of Morals. pp. 67-69.
} 
becomes a breeding ground for the development of the bad conscience. Man begins by defining her by her biological difference from him: this difference he desires with his own body. But because man has attempted to overcome his bodily desires he attempts to overthrow physical desire by cloaking woman with his 'higher' desires. This perverts her because the characteristics with which she is draped are not developed out of who she is at bottom. Woman is made by man into a perverse paradox. She is the seat of his strongest desires, in both the sense of lofty ideals and the body erotic, and the battleground where these desires compete. She is meant to be 'all things to all men,' without a modicum of autonomy.

This placement of the concept of 'woman'-particularly the development of her feminine values is further justified given our previous elaborations on Nietzsche's mytho-allegorical representations of woman and his discussion on woman-as-such. But does it fit into the conversation we have begun to consider between the concept of truth and woman?

Under master morality truth is defined simply as the sanction of the master. As all things associated with the master are essentially tautological, the master is the embodiment of truth. Because the master has the supreme right of naming he alone is in possession of truth. The slave revolt in morality which seeks to trans-value the values (we could just as easily call them truths) of the 
master is, therefore, a revolt of liars predicated on a lie. The slaves justify their revolt by creating another lie, the conjecture of 'God,' and then proceed to lie to themselves about who they are. This becomes perverse as the slave justifies his mendaciousness with recourse to the fallacious 'will-to-truth' behind which, we know, is the will-to-power. The development of the concept of 'truth' therefore mirrors exactly the development of the concept of 'woman.' There is further similarity between 'God' and 'woman' than we have allowed for thus far. Our understanding of the similarity between these two 'creations' of man is integral to our understanding of woman's place under slave morality and to Nietzsche's trans-valuation of the feminine value.

The slave revolt in morality is successful because the slave can justify his inversion of masterly values. The success of this justification (and thus the slave revolt) comes from the development/creation of an outside surveyor-in Judaism and Christianity this outside surveyor is 'God.' 'God' is posited as an objective force outside humanity who gives value to the slave's trans-valuation of masterly values. The slave can now point to 'God' and say 'I am good because the objective 'God' says I am.' The development and success of the religious myth thus solidifies the slave's trans-valuation of values and guarantees the annihilation of master morality. In the case of woman; the slave characterises feminine otherness under the Christian (slavish) 'good'55. This would at first appear to put the slave's definition of woman at odds with itself — how can she be both 'other' and 'good'? As the embodiment of the slave's 'good,' she becomes a desire, an

\footnotetext{
${ }^{55}$ Men may are called upon to conform themselves to these Christian ideals, but Christianity decreed that woman's 'innocence' makes her the natural seat of them. Men must suffer in order to fulfill the requirements of chastity, whereas unchaste women are condemned as 'unnatural'.
} 
aspiration for man. Woman as myth is the value of 'good' become flesh. In positing woman as other, and providing her with 'good' characteristics she becomes a living reminder of the success of the slave revolt in morality. She is an interactive object endowed with an absolute.

The mirror development of 'God' and 'woman' is furthered if we consider the relationships of 'love' which define both concepts. 'God's' love is characterised by the Greek term agapē. This is the 'highest' form of love-it is 'God's' love for his creation. (Agapē is, therefore, the slave's primary justification for the slave revolt in morality.) A descendant love, the 'movement' of agap $\bar{e}$ is always from the higher to the lower. Womanly love, denoted by the Greek word storge $\bar{e}$, is, in essence the same, as agape $\bar{e}$. Or, rather, storge $\bar{e}$ is a reified form of agapē. Characterised as an instinctual (elemental) love, storgē is the love of the mother for her child. In storge, as is the case in agape , the movement of love is descendant.

That woman is a myth for Nietzsche is certain-particularly given his own mytho-allegorical characterizations of her. The male artist/slave creates woman to be a reflection of himself and thus give substance to what he knows is a mere fabrication on his part. In order to impart himself as master the slave needed to 'lie' to himself that the order of values under master morality was false. Effectively, before the slave created the image of 'woman' he created his own image. But he knows that his self-creation is predicated on an inversion of the 'natural' of strong over weak and he therefore needs an objective example to help him believe his lie. The slave first created 'God' to justify his right to invert 
master morality, he then creates 'woman' to justify the inversion. The slave believes 'woman' (the role of the feminine within society) is the justification of the value order he has instituted on humanity.

We have justified our initial assertion that the feminine is an artistic representation for Nietzsche by examining the development of her feminine 'values.' Beginning with the simple 'good/bad' value delineation of the master we arrived at Nietzsche's description of the slave revolt in morality. Through our consideration of the slave revolt we deciphered how the creative slave transformed masterly language and thus created the feminine as a value. That this is a perversion of woman becomes evident through the development of woman's bad conscience. Moreover, the mirrored development of 'woman' and 'God' solidifies the link we originally made between 'woman' and 'truth.' Having justified links which appeared tenuous we may set out with easy hearts on our journey into the intricacies of the conversation between woman and truth. Given that it has become apparent to us that the experience of woman mirrors the development of truth we can safely narrow the parameters of our search to the discussion of a single 'truth,' (a single value): the feminine. By examining the path of this value (truth) in Nietzsche's works we gain insight not only into the general nature of value movement, but we are able to address the explicitly political question concerning the nature of the female sex.

Every good traveller (or at least every time/space limited traveller) begins with a map. Following a map allows the traveller to examine the nooks and 
crannies of peculiar interest to them, and avoid the tantalization of issues of outside concern. Following Nietzsche's own treatment of values our path will have three steps: We shall begin our journey by affirming the present state of perversion of the feminine according to Nietzsche ${ }^{56}$. We shall then, to adopt Nietzsche's own phrase, 'philosophise with a hammer" ${ }^{57}$ and deconstruct the state of perversion of this value in order to engage in the trans-valuation of values. Lastly, we will rebuild the concept of feminine truth, affirming Nietzsche's transvaluation of values. Owing to Nietzsche's view that 'truth' is a necessary lie covering the horrid reality of life, and that the lie of Christianity has outlived its life-preserving service, the philosopher takes it upon himself to develop new myths. It is therefore fitting for us to examine the movement of feminine truth through myths. We shall take the three legs of our journey by examining three mythological women: Echo, Baubo, and Ariadne. Thus we also connect ourselves with our previous examinations of 'truth' and 'woman.' It is only fitting to describe the 'story' of gender with the 'stories' of myths-one creative act deserving of another.

\footnotetext{
${ }^{56}$ Given that Nietzsche was writing in the $19^{\text {th }}$ century and considering the impact of the feminist movements since the publication of Nietzsche's works one could argue that it is odd to suggest that we can use Nietzsche to describe the present situation of women. However, given that Nietzsche's own trans-valuation of values has not been universally adopted the essence of his evaluation on the situation of women remains unchanged in the world of today -in fact 'today's woman' is arguably more perverted than Nietzsche's 'ladies' of the $19^{\text {th }}$ century.

57 'How to philosophise with a hammer' is the subtitle to Nietzsche's Twilight of the Idols, the image of the philosopher with a hammer, however, is first introduced in Thus Spoke Zarathustra in the aphorism entitled "On the Blessed Isles."
} 


\section{Chapter Two \\ Woman's perversion: reflections of Echo}

The disappointed man speaks.- 'I listened for an echo and I heard only praise-.'

-Nietzsche. Beyond Good and Evil

With gender as our compass and mythology as our map we are now ready to embark on the first leg of our journey. Having prepared ourselves for our examination of the conversation of feminine truth in Nietzsche with a consideration of the 'past ${ }^{58}$, -wherein we established the root of false gender valuation—we shall now take our first steps on the road of the 'present ${ }^{59}$.' This 'present' we are examining is in reference to the historical period that we refer to as 'modernity,' and occasionally, in fits of abstraction, as post-modernity. Through this historical lens we shall discover the effect of the created and imposed feminine value on the concept of 'woman.' We are elaborating Nietzsche's considerations of these ramifications through the telling of myths. Our use of myth continues the conversation Nietzsche has begun between 'truth'

\footnotetext{
${ }^{58}$ This is, of course, inasmuch as we accept Nietzsche's Genealogy of Morals to be an elaboration of the historical development of values.

${ }^{59}$ Please see Note 49.
} 
and 'woman,' endowing us with the choice position of being both part of and outside of the conversation. Given this, let us re-tell the story of the (post)modern woman through the myth of Echo and Narcissus ${ }^{60}$.

Echo falls in love with Narcissus, but Narcissus...Narcissus falls in love with himself. To begin, the nymph Echo sees the mortal Narcissus. Struck by his beauty she falls in love with him. Echo wishes to run to Narcissus and proclaim her love for him, but she is held back by one thing. Beyond an ability to repeat what has been spoken to her, Echo is mute. She waits for the young man to speak in order to make her love known, and she is eventually satisfied. The beautiful young man bends over to sate his thirst in a clear fountain. As he bends down he catches a glimpse of himself in the water. He believes his reflection to be a water spirit, a naiad ${ }^{61}$, and he says, 'I love you.' Echo runs to the young man repeating 'I love you!' but she is too late to catch his eye. He is already bound by the beauty of his own reflection. Every now and then Narcissus is so overcome with his own beauty he bends down to give himself a kiss, causing disturbance in the water and the fear of loss in his stomach. Echo burns with the shame of rejection, but stays; watching over him, and repeating his calls of 'Alas! Alas!' as the moments pass by. Both of the lovers waste away; she mourning the loss of him, and he mourning the loss of himself. She becomes nothing more than a repetitive

\footnotetext{
${ }^{60}$ My rendition of the myth of Echo and Narcissus has been taken from my reading of Thomas Bulfinch's 'Echo and Narcissus' available in Bulfinch's Mythology. New York: Modern Library, 1998. pp. $95-9$

${ }^{61}$ Naiads are water nymphs. We must therefore, conclude that Narcissus believed his reflection to be female. This confusion supports our assertion that men paint women with their own characteristics.
} 
voice hiding amongst mountains and caverns, and he dies to transform into a flower.

The reasoning behind our choice of myth is obvious. Echo, with her repetitive flaw, personifies our notion of the feminine in Nietzsche. Hers is a limitation of language. She cannot define herself because she does not have the words. She waits for others to define her and then describes herself in those terms. Echo is ensnared by love, and it is a love she can only echo back to her lover. In order for Echo to define-give form to-her love, Narcissus must first fall in love with himself. Echo's love is therefore nothing more than a re-iteration of Narcissus' own. And who is Narcissus beyond his self-love? Nothing. His self-enchantment and satisfaction is all consuming-it is who he is. Narcissus is the only subject in this myth. Echo, as a result of her muteness, can only be an object. She is contingent upon Narcissus.

This myth is also fitting given the natures of the two characters. Echo is an immortal nymph; although her only vestige of immortality is her ridiculous habit of repeating what is said to her; other than this she has no substance and is further relegated to the role of object. Echo's immortal position connects her with our previous discussions on the similarities between the conjecture of 'God' and the conjecture of 'woman.' Narcissus is mortal and his love lasts until his physical body wastes away. His self-love, however, collapses being and becoming. Narcissus is in love with the reflection of himself, but his feelings of love are deified as opposed to reified because he believes himself to be in love with an immortal spirit. Though his love is captured by the limits of his own 
mortality and he is therefore trapped in the cycle of 'becoming;' through his deification of his reflection Narcissus attempts to elevate himself to 'being' and thus escape his mortality. Echo partakes in this blurring of the boundaries of 'being' and 'becoming' by herself falling in love with a mortal man.

These above assertions take us no further down our chosen path than our past inquiries. In order to move forward we must follow the one overarching link between what we have said before and where the myth now leads us. This is the path of love: an all consuming and insatiable love which leads to the slow destruction of the lovers. We shall examine love, as it is characterised by the myth of Echo and Narcissus in order to understand the present ramifications of creation and imposition of the false gender on woman in Nietzsche's work.

Let us return to the case of Echo and pay closer attention to the nature of her love. We have said that Narcissus must first fall in love with himself in order for Echo to manifest her love for him. We have also said that Echo is only defined by the subject who speaks to her. In the case of the above myth, therefore, not only does Narcissus' declaration of his self-love allow Echo to call forth her love for Narcissus, but it as well defines Echo. She is her love for Narcissus. Moreover, because she is condemned to repeat back to the speaker whatever is spoken to her, we realise that Echo is in fact Narcissus' reflection. She returns to him whatever desires and demands he speaks to the world. The tragedy lies in the fact that Narcissus will never recognise Echo as his beloved. They are separated by an impenetrable barrier. He cannot see her, but only 
himself and believes he is thus in love. She is entirely encapsulated by her desire for someone who will never respond to her because she is unrecognizable. Furthermore, through her love for Narcissus Echo loses her physical substanceshe becomes nothing more than the echo of her name. Echo's love for Narcissus is thus predicated on her own loss of self. Through this loss of physical self Echo fully becomes Narcissus' reflection—she is nothing but what Narcissus says of her and her substance is directly descended from this.

Echo's love for Narcissus is a chaste love, although she wishes it were otherwise. It can never be anything else because he will never acknowledge her. The importance of this lies in its unproductivity. Although Echo desires Narcissus he will never fulfill her desire, her love for him will never bear fruit. Her wish to unify with Narcissus is attempted given her reflection of him (through her repetition of his words) but this attempted unification is never actualised. Her love is an idealised love based on possibility as opposed to actuality. Echo is in love with what might be as opposed to what actually is. This is her downfall. She wishes to be partnered but recognises that she is alone. This loneliness becomes ostensible through her chastity; she will remain alone even though she is in love. Echo's loss of physical substance ensures that she will remain forever chaste and believing in an ideal love. She is immortal through her continued reflection of others, but she will never have the immortality conferred on her by the production of children.

We must also consider the nature of Narcissus' love in this myth as he is the catalyst of Echo's. We have already stated that Narcissus is also defined by 
his love. However, whereas Echo's love is that of lover, Narcissus' love is that of both lover (of himself) and beloved (of Echo and himself). Narcissus' effect on Echo occurs unbeknownst to him as he is already ensnared by his own beauty. She cannot compete with the vision of perfection he sees in himself. Narcissus is the actor in the myth, but he is unable to act (and is unaware of his own agency) because he is spellbound by himself. Narcissus' self-love is interesting to us because he is unaware that it is self-love. This becomes more intriguing if we accept what we said before, that it is in fact Echo, with her repetitive curse who is Narcissus' reflection. Narcissus is unable to recognise himself, and it is his inability to know himself which allows him to be ensnared by the naiad of his reflection. But this in no way lessens the fact that Narcissus loves only himself. What Narcissus is intrigued by in his watery reflection are his human qualities made divine.

Narcissus' love is auto-erotic, and therefore is as unfruitful as Echo's chastity. Narcissus' attempts to 'make love' to his watery reflection manifest an impossibility, and he cannot tear himself away from the image in order to see the tangible reflection of Echo. The unproductivity of Narcissus is a greater tragedy than Echo's chastity - Narcissus is mortal and he will die. Narcissus participates in immortality only in the role of flower-which is itself caught in the cycle of becoming. The auto-eroticism of Narcissus implies a strong sexual impulse which is not present in Echo. Narcissus' attempts to kiss (make love to) his visible reflection are obviously continually foiled. But beyond this, with each attempt Narcissus disturbs the water and thus disturbs his image of himself. The 
disturbed image terrifies Narcissus because he feels he has lost his beloved; he is only calmed when the water itself becomes calm. Narcissus' reflection is the embodiment of his 'immortal soul.' His fear of loss is thus explained as a fear of death. Or, the idea of losing his deified self is a fear of the world as becoming. This loss can further be seen as a 'punishment.' Narcissus is 'punished' with the loss of his beloved as a result of his erotic overture. Narcissus is as alone as Echo, but he does not recognise his loneliness. He believes the water spirit of his reflection to be his constant companion. This companion, however, can offer very little by way of companionship.

What are 'the things people call love' for Nietzsche ${ }^{62}$ ? Nietzsche understands love through the lens of the will-to-power. We fall in love because we want to possess the beloved. Love is, according to Nietzsche, by no means a selfless desire, but one of the ultimate manifestations of selfishness. When we love we attempt to justify the pleasure we have in ourselves by 'changing something new into ourselves ${ }^{63}$.' The lover would like to keep the beloved away from all competitors and thus deprive the world of a 'precious good, from happiness and enjoyment ${ }^{64}$.' Nietzsche suggests that the instinct which we call love is no different from that which we call avarice. The lover in possession of the beloved is avaricious; wanting, as they do, the beloved only for themselves.

${ }^{62}$ Nietzsche. The Gay Science. Aph. 14.

${ }^{63}$ Nietzsche's emphasis. Ibid.

${ }^{64}$ Ibid. 
The desiring lover turns this avaricious instinct into a good-hence our present associations of love ${ }^{65}$. Those desirous of love have had the luxury of naming and defining the concept of love. Although Nietzsche initially suggests this is a result of more suffering the want of desire than the contentment of satisfaction, he comes to believe that it is in fact a result of us 'ultimately [loving our] desires and not that which is desired ${ }^{66}$,

The myth of Echo and Narcissus illustrates this. Through her repetitive habit Echo becomes Narcissus' true reflection. She is transformed into him. But Narcissus does not recognise the satisfaction of his desire in Echo; rather he is focused on maintaining his link with his watery reflection whom he can not 'have.' Narcissus wastes away because he can not stop looking at himself in the water-this is his avarice. He will not look away because he is afraid he will lose his 'beloved.' His vigilance over himself is all-encompassing and self-defeating in that he is doomed to experience the loss of his reflection as he kills himself through neglect.

Here we must stop to consider love's specific effects on women as they are defined by Nietzsche. When we began we separated Nietzsche's writings on woman into the categories of mytho-allegorical representations and woman-as$\operatorname{such}^{67}$. Both categories contain love relationships. The love characterised by Nietzsche's mytho-allegoric women is, however, of a different nature than the love we are attempting to understand here. Given that Nietzsche's mythoallegoric women are designed to represent Nietzsche's highest values, they are in

${ }^{65}$ Ibid.

${ }^{66}$ Nietzsche. Beyond Good and Evil. Aph. 175.

${ }^{67}$ Introduction. p 11. 
fact a part of his trans-valuation of values and thus do not belong here, among the 'present.' We must therefore limit our discussion to Nietzsche's observations on woman-as-such.

In Human, All Too Human, Nietzsche provides an aphorism (entire quote provided) which suits our needs nicely.

Love. The idolatry that women practice when it comes to love is fundamentally and originally a clever device, in that all those idealizations of love heighten their own power and portray them as ever more desirable in the eyes of men. But because they have grown accustomed over the centuries to this exaggerated estimation of love, it has happened that they have run into their own net and forgotten the reason behind it. They themselves are now more deceived than men, and suffer more, therefore, from the disappointment that almost inevitably enters the life of every woman - to the extent that she even has enough fantasy and sense to be able to be deceived and disappointed ${ }^{68}$.

This aphorism begins by reminding us that in love woman is the desired object and not the desiring subject. Or rather, it is woman's desire to be desired by man. Women desire the idea of love more than they desire love. In order to satisfy her desire woman engages in an 'idolatry of love.' She creates an idealised form of the emotion and thus gives it a value. Love is, therefore, made 'good' and through this woman hopes to make desire desirable. But in creating this value, woman has laid herself on the altar she had created for someone elseshe has been entangled in the net she created knot by knot (ideal by ideal) ${ }^{69}$. Although men will still lay themselves down on the altar of love, woman has created a permanent residence for herself at the feet of her idol.

\footnotetext{
${ }^{68}$ Nietzsche. Human, All Too Human. Aph. 415. The different estimations of love between the sexes are also considered by Nietzsche in The Gay Science Aph. 363.

${ }^{69}$ Nietzsche. Beyond Good and Evil. Aph. 269.
} 
Woman has forgotten the reason behind her valuation of love, according to Nietzsche. Moreover, she has now made love her own highest value! She has mistaken her own desire for the desire she sought to create in men. The case of Echo exemplifies this. Echo wishes to make Narcissus fall in love with her, but the path she chooses to take in order to actualise her desiring of his desire is flawed from the outset. Her repetition of Narcissus' own proclamations of love, directed, as they are, not at her but at himself, automatically negate the possibility of him recognizing her as his desire. Echo has begun by mistaking her love for the possibility of love-her idealization of love-for love itself. In this way, Echo, as she characterises woman-as-such in Nietzsche's present, has attempted to transform herself from the beloved into the lover-she has mistaken her role. Because of her mistaken role, and because she has sacrificed herself on the altar of love, Echo suffers more than Narcissus from the lack of love. She is aware that she is meant to be (and truly is) his beloved. Echo is aware of the pathos of both her own love and Narcissus'. This leads to the disappointment Nietzsche refers to in the aphorism. It is a disappointment which is born from the beloved withholding himself. This is a disappointment that Echo, as woman-as-such, creates through her love. By loving Narcissus, Echo eliminates the possibility of him satisfying her own desire to be desired; for, as Nietzsche writes, 'to discover he is loved ought really to disenchant the lover with the beloved ${ }^{70}$.

Nietzsche also writes that woman's disappointment in love comes as a result of believing, through her exaggerated valuation of love, that her love is utterly satisfying to her beloved. She discovers, much to her horror, that her

\footnotetext{
${ }^{70}$ Nietzsche. Beyond Good and Evil. Aph. 102
} 
proclamations of love have exactly the opposite effect she would wish them to have. In declaring her love she has attempted to wrest the position of lover from man. However it is not her love that attracts him but her 'otherness,' or in Nietzsche's words 'precisely that she seemed utterly changeable and unfathomable ${ }^{71} . \quad$ In adopting the role of lover woman misunderstands the relationship between lover and beloved. It is the goal of the avaricious lover to make the beloved part of him. Because woman as we know her in the 'present' is man's creation, she is therefore nought but an aspect of man. How then does she fit into the lover/beloved dichotomy? She can be neither beloved nor lover because she is already an aspect of man. But here we must remember that man has 'forgotten' that he has created 'woman' just as he has 'forgotten' he has created 'God.' Thus woman 'appears' to be separate from man. This separation of woman from man cannot endow her with the role of lover, however, because, although forgotten, the fact of her creation has not been done away with—she is still a reflection of him. He is the lover, and she the beloved.

This explains Echo's hopeful declaration of love, and her dissatisfaction with the lack of a return declaration. Echo, as repetition of Narcissus, is too like Narcissus for him to notice her. His watered reflection, as it changes with his attempted love-making, is more desirable to Narcissus. Narcissus' love for his reflection accords with the relationship between lover and beloved. Echo, as Narcissus' true reflection, denies herself the role of beloved by reflecting Narcissus' own role of lover. He makes his watery reflection his beloved through

\footnotetext{
${ }^{71}$ Nietzsche. The Gay Science. Aph. 67
} 
his inability to recognise it as such ${ }^{72}$. Narcissus wishes to possess his reflection. His inability to possess the 'naiad' of himself only strengthens his desire for it. The problem of love and woman for Nietzsche is thus the problem of lover versus beloved. Through her creation of the idol 'love' woman forgets this relationship. She attempts to adopt the role of lover forgetting that this role not only results in her own dissatisfaction, but is impossible for her in her 'present' incarnation. She forgets that she satisfies his desire by declaring her own love; that by her declaration she becomes a recognised part of him. When she adopts the role of lover she resembles him and he 'remembers' who she is in relation to him, that she is not 'other' but a manifestation of his will-to-power. In recognizing this man is satisfied, he recognises his mastery over her and is rewarded by her loving recognition of him. This is the paradox of love.

Nietzsche states that woman is not only 'disappointed' with love, but she is as well 'deceived.' The first deception to arise out of woman's idolization of love concerns its nature as a value. When woman elevates love to the value of 'good' she cleanses it of its 'evil' aspects. Because of this love loses its avaricious undertones. But this also means that love loses its connection with the body. This is owing to the fact that our 'present' is still characterised by the values of slave morality whereby the body and bodily desires are castigated. Love, the 'good,' has, therefore, only vague and idealised connections with sexual love $^{73}$. Woman's conceptions of sexual love thus become a source of shame-an

\footnotetext{
${ }^{72}$ The notion of water as 'beloved' forms the basis of Luce Irigaray's examination of Nietzsche and woman. (Luce Irigaray. Marine Lover of Friedrich Nietzsche. Trans. Gillian C. Gill. New York: Columbia Universtiy, 1991.)

${ }^{73}$ Nietzsche. Beyond Good and Evil. Aph. 114. and The Gay Science. Aph 59.
} 
aspect of her bad conscience. The base body should have no role in the value of love.

The idealization of a higher 'chaste' love and the confusion over sexual love occur concomitantly in our relation of the myth of Echo and Narcissus. Echo's highly idealised love for Narcissus exemplifies the elevation of 'chaste' love. Echo desires Narcissus (we know that this is as well a sexual desire), but the shame of his rejection of her causes Echo to further idealise love. She loses her physical body, and thus the possibility of sexual love, through her sacrifice to this conception of ideal love.

Narcissus' auto-eroticism illustrates the confusion of sexual love. Narcissus' attempts to make love to the 'naiad' of his reflection will always result in the obfuscation of the image in the water. Thus is sexuality in the myth rendered either idealised and obsolete (in the case of Echo) or confusing and destructive (in the case of Narcissus). In either situation we are faced with the deceit of foiled expectations. This is the original deception in love.

Woman is also deceived in her love by her transformation of the beloved into a god in the pantheon of her idolatrous temple. In loving him, she elevates the beloved's 'rare and exceptional qualities ${ }^{74}$.' This elevation of the beloved causes woman to deceive herself as to the normalcy of the beloved. In the myth of Echo and Narcissus, it is Narcissus who first elevates his own qualities-through his belief that his reflection is a semi-divine (and immortal) naiad. Echo affirms this elevation with her own declaration of love, thus 'deifying' Narcissus through her love. Echo no longer considers Narcissus a mere mortal man-he is her

\footnotetext{
${ }^{74}$ Nietzsche. Beyond Good and Evil. Aph. 163.
} 
beloved and her idol. She worships him by her attentiveness to his prostrate form. She can worship him in this way, moreover, because he will never alter the expectations of her idealised love-she is capable of absolutely deceiving herself concerning Narcissus' qualities. In the religion of Echo's love Narcissus is made god as she says her love declaration prayers.

Woman enters into the love relationship aware of her role as beloved. In order to fulfill this role woman must reflect man's desires. This is logical. In order to stimulate desire one must make oneself desirable ${ }^{75}$. However, in making herself desirable to man, woman falls in 'love' with the very thing designed to make her desirable - the 'good' (the value) of love. The effect of this on woman is devastating. She becomes confused; she forgets her role and adopts the role of lover. Her adoption of the role of lover leads to her suffering deceit and disappointment. This relationship of love is personified absolutely by the myth of Echo and Narcissus - theirs is a love inherently based on deceit and undeniably characterised by disappointment. That this leads to their suffering is unquestionable. Only Echo, however, is devastated by this love. Although unaware of the reasons behind it she is aware of its failure. Narcissus' love pangs come as a result of his inability to recognise his beloved. His suffering comes from a lack of knowledge. Echo in her awareness, on the other hand, suffers from a twofold loss. She loses her beloved and she loses her self. The tragedy of the myth lies in the suffering of Echo over that of Narcissus.

\footnotetext{
${ }^{75}$ Nietzsche. Human, All Too Human. Aph. 400
} 
But what is the root of woman's difficulties with love? We are tempted to say her idolization of love is the issue, but this is incorrect, or at least, partially incorrect. For, as Nietzsche states in the aphorism, "the idolatry that women practice when it comes to love is fundamentally and originally a clever device.' Woman's difficulty with love begins not with her idolization of love, but with her subsequent belief in the idol she has created. Simply used as a device in order to receive satisfaction for her desire of man's desire, love is a clever tool. The radix of her problem with love is her 'forgetfulness.' When woman 'forgets' that her idolization of love is a tool for achieving, a means, and begins to believe in the dissimulation she has created she has fallen into her own trap. These difficulties are further intensified when she attempts to play the role of lover as opposed to her optimal power position of beloved.

When woman chooses to adopt the characteristics of the lover she loses her ground and the power of her position. Man wishes woman to be everything within him and outside of him, thus he defines her as; 'something more delicate, more fragile, more savage, stranger, sweeter, soulful ${ }^{76}$, This is his artistry, his creation of the feminine values which woman then forms herself around ${ }^{77}$. He creates her as an 'ideal other,' and then 'forgets' this act of creation. His 'belief' in her otherness is what attracts him. Man, as moved by the will-to-power, wishes to assert his dominion over the 'other' known as woman. He wishes to negate her otherness by making her part of himself (unaware of the fact that in this

${ }^{76}$ Nietzsche. Beyond Good and Evil. Aph 237 and Aph 239.

${ }^{77}$ Nietzsche. Beyond Good and Evil. Aph. 131 
manifestation she already is). When woman acts as the lover she is subverting this order. It is a failed attempt on her part to wrest agency away from man. This is an incredible catastrophe for woman; not only is she unable to escape from under her imposed feminine otherness, but she loses the power allotted to that position—she is Echo losing her self and her beloved.

By adopting the masculine role of lover woman attempts to emulate man. But why does woman wish to emulate the masculine gender? Let us review what we of know of woman as Echo. She is denied the right to name herself, in order to define who she is she must be told by someone else. By conforming to this definition she participates in the world in the only way open to her. Her only participation in this world-this 'present'-is as an object. She is something which is acted on, as opposed to someone who acts. In the words of Nietzsche she is willingness as opposed to will. Hers is a more difficult position — she must hide her will-to-power under the cloak of willingness. Echo, with her repetitive curse clearly understands this. She is willingness personified. The difficulty of this position is great as it undeniably leads to the loss of self (or, presupposes that the self never existed). In an attempt to gain substance, to become part of the world she is barred from, Echo adopts the characteristics of the actor in the myth; she attempts to become an active lover. However, even in this she can only be a reflection. Her reflection of masculinity is an even greater perversion of herself than the imposed gender of femininity.

Woman acting as man is a further perversion of who she is because, by this, she absolutely loses herself. We see this exemplified in Echo's loss of 
physical self as she adopts the masculine characteristics of lover. Whereas, life under the imposed gender of femininity is merely unbearable, life for women who adopt masculine characteristics is schizophrenic. By adopting masculine characteristics, woman attempts to deny not only the imposition of femininity but her biological reality as well. This is, quite simply, insane and it invariably leads to insanity.

It is Nietzsche's view, moreover, that the masculine gender is infinitely more perverse than the feminine. This is owing to the fact that man is more disconnected from his natural (animal) instincts than woman. Rather, the position that was created and which woman fulfills has been almost entirely based around her biological capability of the production of children ${ }^{78}$. Man, and we can see this in Narcissus' conflation of being and becoming, has taken as his goal the impossibility of removing the animal from himself ${ }^{79}$. Woman as she attempts to become more like man, must therefore as well attempt to do away with her natural/animal self; to do away with her sole possession—her body.

The fundamental characteristic of this 'present' is nihilism. Nihilism in this myth is perhaps most obvious in Narcissus' love for his 'empty' reflection. This is an exemplification of the value of love losing its foundation and content. Narcissus is not, however, the seat of nihilism in this myth because he is unaware of his situation. Echo, who perceives the tragedy of their situation, becomes trapped in the midst of their nihilistic situation. Echo is aware that Narcissus' love has no content and her attempt to rectify (reconnect) the situation (through

\footnotetext{
${ }^{78}$ As we have already discussed, the role of woman as lover has heretofore been characterised as storge e: the instinctual, motherly love. (Chapter One, p 35.)

${ }^{79}$ Nietzsche. Genealogy of Morals. Aph. 7.
} 
her adoption of the characteristics of lover) only further remove the value of love from its axis. Echo's wallowing in the schizophrenic experience of nihilism is characterised by her loss of physical self. She becomes nothing, a reflection of the loss of value of idealised love.

Life denying nihilism is the ultimate ramification of the imposition of the feminine gender on woman. Nietzsche would have us understand these life denying characteristics in their broadest possible sense. Herein we find the denial of physical and psychological life-imposition of feminine truth is inherently unproductive. Physical life is denied through the idealization of love leading as it does to the promotion of the separation of the human totality into body and soul. Psychological life is denied as we reach the point of creative stasis developed through the promotion of the separation of body and soul. Because of its lifedenying nature, the feminine value is therefore one which must be overcome. We shall here depart from Echo and Narcissus, and continue on our journey upwards - for now we must engage in the overcoming of the imposed feminine value. 


\section{Chapter Three \\ Deconstructing 'woman': Baubo's ridiculous exposure}

Perhaps truth is a woman who has reasons for not letting us see her reasons? Perhaps her name is-to speak Greek-Baubo?

Nietzsche. The Gay Science.

Having completed the first leg of our journey we are now aware of the difficulties of the path we have chosen. Following our travels through the present on the path of love, where we considered the effects the imposed feminine value has on woman through the myth of Echo and Narcissus; we are now prepared to embark on the second stage of our journey. This second leg involves our deconstruction of the value of the 'feminine.' Here we shall 'philosophise with a hammer' and follow Nietzsche's trans-valuation of values. We shall break the old tablets of values in order to allow for new value creation ${ }^{80}$. We must consult our map once more for now we shall leave Echo to her repetitions in the caverns

\footnotetext{
${ }^{80}$ Nietzsche. "On Old and New Tablets" Thus Spoke Zarathustra. pp. 308-327.
} 
below us and continue our journey. Thus having finished with Echo we shall turn to $\mathrm{Baubo}^{81}$.

When Persephone was stolen by Hades, Demeter was inconsolable. She travelled the world relentlessly searching for her beautiful daughter, but Persephone was nowhere to be found. Demeter lost hope, and in her sorrow she enveloped the world in its first winter. All was cold and grey. Demeter decreed that the earth would remain barren as long as her daughter was kept from her. She continued to search but now she travelled listlessly, accepting neither food nor drink. In her searching travels she arrived at the Court of King Celeus in the Eleusis, where an old woman, Baubo, succeeded in raising her spirits and thus returning fertility to the earth. How did Baubo raise the spirits of Demeter? Simply by making her laugh. How did Baubo make Demeter laugh? She lifted her skirts to show the goddess the face of Iaachos (Demeter's son) painted on her stomach, exposing her vulva in the process ${ }^{82}$.

We choose this myth because Nietzsche chooses it. Nietzsche's reference to Baubo (provided in the quote which heads this chapter) mirrors the opening

\footnotetext{
${ }^{81}$ Adapted from Sarah Kofman's adaptation in 'Baubo: Theological Perversion and Fetishism' in Nietzsche's New Seas. Eds. Michael Allen Gillespie and Tracy B. Strong. P 196.

${ }^{82}$ Of course this is only a part of the myth of Persephone's kidnapping - and an obscure aspect at that. We know that Demeter eventually discovers that her daughter is being held by Hades in the underworld. On discovering this she returns to Mount Olympus to plead with Zeus for Persephone's release. Zeus agrees to force Hades to return Persephone on one condition: Persephone can not have eaten any of the food of the underworld. During her long stay with Hades, Persephone's anguish was too great for her to eat; but upon discovering that she will return to her mother Hades offers her a pomegranate. Persephone eats a single seed-and this single transgression ensures that Hades will not lose his beloved. Rather, Persephone's time is divided between over and underworld. She spends half her time with her mother, and the other half with Hades-who has become her husband. During Persephone's stay with her husband Demeter's sorrow returns and the development her sorrow is marked by the return of winter. According to Robert Graves this myth illustrates not only the development of the yearly seasons but is also illustrative of the creation of the poetic meter known as iambic pentameter and stands as the beginning of the festival of the Eleusian mysteries.
} 
line to the preface of Beyond Good and Evil ${ }^{83}$. The similarity between these quotes makes it impossible for us not to consider who Baubo is for Nietzsche. Moreover, the addition of the character of Baubo to Nietzsche's suggested relationship between truth and woman obviously furthers our examination into both. Nietzsche's choice of Baubo becomes obvious to us when we consider the nature of his reference to her in light of our understanding of the myth her story forms. The importance of Baubo for Nietzsche lies in the concept of exposure. It is important for us to discover how exposure relates to Nietzsche's task and, consequently, our own. To do this we must turn momentarily away from the myth of Baubo and consider two others of Nietzsche's mythological favouritesDionysos and Apollo. We shall begin with Dionysos and the dionysiac, as Apollo and the apolline follow from Nietzsche's consideration of Dionysos.

Dionysos is the Greek god of wine. He is therefore closely associated with intoxication and the fall-out from intoxication; particularly sexual promiscuity. In keeping with this, the dionysiac is, using Nietzsche's own description, "best conveyed by the analogy of intoxication [which] cause[s] subjectivity to vanish to the point of complete self-forgetting ${ }^{84}$, Through his association with intoxication and ecstasy, Dionysos dissolves mankind's created individual boundaries and reconnects humanity to the general element of life ${ }^{85}$. Thus Dionysos is described by Nietzsche as the artist of humanity—-for out of this

\footnotetext{
${ }^{83}$ Both Beyond Good and Evil and the preface to the Second Edition of The Gay Science (from which this quote was taken) were published in 1886 . They are logically, therefore, from the same stage in Nietzsche's philosophical development.

${ }^{84}$ Nietzsche. The Birth of Tragedy. Aph. 1.

${ }^{85}$ Nietzsche. Dionysiac World View in The Birth of Tragedy and Other Writings. 120.
} 
general element of life the human being is shaped ${ }^{86}$. Through dionysiac ecstasy (produced by narcotic stimulants and/or the beginnings of spring) we, therefore, encounter natural reality ${ }^{87}$. The effect of this unmediated experience of nature is the destruction of the boundaries we have created amongst ourselves and with the world that surrounds us. The encounter with natural reality provided by the dionysiac experience is not, however, necessarily in the service of life-affirming goals. Rather we are told by Nietzsche that this untempered experience of the dionysiac is truly terrible. Without a moderating force between us and the dionysiac, we become horrifyingly aware that all life is nothing more than the cycle of becoming. This realisation drives us insane. All things come to be and then pass away, we, like all animals, shall die and once more be devoured by the Earth-the first mother who could be said to eat her young. Moreover, the entirety of our existence is marked by great suffering ${ }^{88}$. Hence, Silenus ${ }^{89}$ assertion on humanity's greatest good: 'the best is not to be, the second best to die soon $^{90}$ ?

Because of the horrific truths Dionysos and the dionysiac reveal, and in order to prevent our insanity at the hands of these truths, our experience of this revelatory god is tempered through the apolline. Apollo, the sublime sun god, is the god of the beautiful dream. When he enters into partnership with the terrible Dionysos (interpreted by Nietzsche as occurring when Apollo heals the body of

\footnotetext{
${ }^{86}$ Ibid. p 121.

${ }^{87}$ Ibid.

${ }^{88}$ The experience of human suffering in Nietzschean terms is perhaps best described by the fictional account of the Grand Inquisitor in Dostoevsky's The Brother's Karamazov.

${ }^{89}$ In Greek Mythology Silenus is recognised as Dionysos' teacher and foster father.

${ }^{90}$ Nietzsche. 'Dionysiac World View' Birth of Tragedy and Other Writings. $\mathrm{p} 124$.
} 
the dismembered Dionysos ${ }^{91}$ ), the human experience of the dionysiac is tempered. The frenzied horror associated with dionysiac festivals becomes 'beautified' and digestible by its partnership with the apolline $\mathrm{e}^{92}$. The product of this partnership is characterised according to Nietzsche by the rise of Greek tragedy. This partnership, which is successful provided the tension between the two gods is maintained, comes to favour Apollo over Dionysos.

Nietzsche asserts that this favouring of one god over the other began with Socrates as we know him through Plato ${ }^{93}$. Nietzsche suggests that Socrates' distaste for the dionysiac chaos of Greek tragedy arises out of Socrates' misunderstanding of the dionysiac experience. Based on this lack of understanding Socrates passes a judgement on Greek tragedy which bears directly on the delicate relationship between Apollo and Dionysos: he advocates disrespect for the art form ${ }^{94}$. This advocacy of disrespect for Greek tragedy arose in the socratic school of thought because of its emphasis on logic and reason. Socrates, the rationalist, could not account for the dionysiac experience as it was given in tragedy, and he thus discounted the experience. As Nietzsche writes concerning Socrates' reaction to the dionysiac in tragedy, Socrates saw in tragedy,

\footnotetext{
${ }^{91}$ Ibid.

${ }^{92}$ E.R. Dodds suggests that this division of power between the two deities comes as a result of Düring's proposal that 'divine madness' only enters Greek culture with the introduction of Dionysos. This suggestion is largely based on Homer's lack of reference to any form of insanity. (E.R. Dodds. The Greeks and the Irrational. Berkeley: University of California, 1973. pp. 68-69.) ${ }^{93}$ Socrates' role in the development of western philosophy is of epic and mythological proportions. Much of the intrigue surrounding this father of philosophy arises from the fact that Socrates himself made no record of his philosophical endeavours-we only know him through the work of others. (On an aside, does this not lead to interesting suggestions concerning the relationship between the philosopher and the philosophic task?) Plato is regarded as one of the two primary sources for information and insight into the elusive Socrates. (Xenophon being the other most commonly accepted source.) Nietzsche makes it abundantly clear in his works that his greatest issue with Socratic thought is derived from the Socrates of Plato. As such, any further reference to Socrates in this thesis will reflect Plato's beautified portrayal of the philosopher.

${ }_{94}$ Nietzsche. The Birth of Tragedy. P 64.
} 
'something quite unreasonable, with causes which apparently lacked effects and effects which apparently lacked causes, while the whole was so varied and multifarious that it was bound to be repugnant to a reflective disposition, but also dangerous tinder for sensitive and easily aroused souls ${ }^{95}$.

Given his inability (in Nietzsche's view) to understand tragedy, Socrates became the rational opponent of the art form, claiming it to be nothing more than a series of lies ${ }^{96}$. By announcing himself an opponent of tragedy, Socrates also becomes an opponent of Dionysos and the dionysiac reality of the natural or 'apparent' world. Socrates justifies his condemnation of the world of appearance by nominating a new 'reality': nothing more, nor less than an unmitigated appolline tendency - the socratic "form" ${ }^{97}$. The eternal forms exist outside of the natural world of appearance. We can only experience them as a result of radical transcendence; when we are able to briefly escape the bonds of becoming and touch the eternal logos. The elevation of socratic ideals (as expressed in Plato) reached its apex with the rise of Christianity-Nietzsche's 'Platonism for the masses ${ }^{98}$.' The biblical story of Jesus Christ wherein the 'word' becomes flesh is the perfect example of humanity's contact with the socratic form.

With the triumphant rise of Christianity, the dream-like apolline veil descended on the Western world, gagging Dionysos and the dionysiac in its

\footnotetext{
${ }^{95}$ Ibid. P68.

${ }^{96}$ Socrates specifically attacks tragedy in Plato's Republic while engaged in the task of creating the Kallipolis (the city in speech). His diatribe against the arts is introduced at the end of Book II (377a) and carried throughout Book III.

${ }^{97}$ The conception of the forms essentially concerns the elevation of the rational 'idea.' Very briefly, a fish exists which lives in the ocean, we know it exists because we are able to apprehend it with our senses. But this apparent world of the fish in the ocean is merely covering the 'real' world of ideas. Therefore the fish in the ocean is not as truthful as the idea of the fish which lives in eternal noetic world.

${ }^{98}$ Nietzsche. 'Preface.' Beyond Good and Evil.
} 
descent. By forcing the dionysiac underground humanity becomes disassociated from the natural world. We are asleep under the blanket of Apollo, and our acceptance of the apolline dream causes us to deny natural reality. The separation of the human race from the natural world has been catastrophic for both. In the case of humanity-emphasis on the dream-like veil of Apollo has led, through Christianity, to a belief in a world radically separate from the temporal one we inhabit (heaven); a world which, moreover, does not resemble natural life ${ }^{99}$. Heaven in Christian description is an exclusionary world where humans no longer compete with nature for dominance. Heaven is restricted to men and women with entrance reserved for those who have rid themselves of all ties to the natural world. The rush to enter heaven and begin the afterlife is, therefore, characterised in this world by the attempted 'deletion' of 'nature' from the human totality. This effectively translates into a denial of the body; a denial of the animal within the human ${ }^{100}$. A result of the vindictive slave's anthropomorphic arrogance, humanity is taught to believe that the race is more than merely animal because of its 'participation' in the eternal. We justify and elevate the eternal aspects of our nature through our celebration of the afterlife- the life everlasting which we shall partake in once we have rid ourselves of our bodily cages. The belief in an outside world of greater importance than the one of our daily existence has 'allowed' us to destroy our temporal prison-the earth of our present. As our

\footnotetext{
${ }^{99}$ This second world-heaven-is characterised by eternal being, and therefore does not resemble 'life' - which is fundamentally the cycle of becoming.

${ }^{100} \mathrm{By}$ this I refer to Christianity's role in bodily denigration as it is exemplified by such practices as fasting and celibacy.
} 
eyes and ears remain covered by the veil of Apollo we continue to live under the values dictated by Christianity ${ }^{101}$.

As we have said before ${ }^{102}$ Nietzsche's difficulty with the Christian dissimulation is not a result of it being a lie (although he capitalises on its falsity in order to deconstruct it), but rather that it is no longer successful in providing humanity with a goal. Because heaven and the afterlife are no longer able to cause human striving and overcoming, Judaeo-Christian values, as the longest lasting examples of the triumph of slave morality, must be overturned as masterly values were previously. The destruction of Christianity must be the complete trans-valuation of values, hence Nietzsche's unflinching and irreverent attack on all Christian dogma and doctrine. Awaking the Christian herd, who embrace values of death over those of life, is therefore an aspect of Nietzsche's goal. In other words, Nietzsche seeks to lift the veil of Apollo and expose the natural world through the dionysiac experience. The character of Baubo embodies this exposure. By her exhibitionism, which is in itself a characteristic of the dionysiac, Baubo lifts Apollo's veil ${ }^{103}$. Through Dionysos, as he is exposed by Baubo, humanity is reconnected (re-tuned) to the natural world.

The exposing myth of Baubo therefore has an explicit relationship with Nietzsche's elaborations on the relationship between Apollo and Dionysos. In the

\footnotetext{
${ }^{101}$ Nietzsche. "New Struggles" The Gay Science. aph. 108.

${ }^{102}$ Chapter One. P 30

${ }^{103}$ Sarah Kofman writes particularly on Baubo as an example of the dionysiac in her work entitled: 'Bâubo: theological perversion and fetishism'. (Available in Nietzsche's New Seas. Eds. Michael Allen Gillespie and Tracy B. Strong. pp. 175-202.)
} 
myth of Demeter and Baubo the feminine drama of Apollo and Dionysos plays out. Demeter's denial of her role as goddess of fertility is reminiscient of the descending veil of the appolline. As suggested above, Baubo adopts the role of Dionysos within the myth. She fulfills her role through her self-exposure. By this exposing act Baubo reconnects Demeter with her nature. Similar to humanity's denied natural 'animalistic' role; Demeter has hidden who she is from herself. Through her self-denial perpetual winter falls over the natural world like a shroud. When Baubo lifts her skirts she lifts the veil of grief from Demeter and thus removes winter's shroud from the earth. Demeter laughs and spring arrives.

But why does Baubo's lifting of her skirts have this effect on Demeter? Baubo exposes herself to Demeter to show the goddess a picture she has drawn of Demeter's son on her stomach. The connection between new life-the drawing of Iaachos - and the reality behind the production of life-Baubo's vaginacause Demeter to laugh. Baubo adopts Demeter's role by drawing Iaachos' face on her belly and exposing her vulva; she embodies Demeter's fecundity. While her skirts are down covering this affected fertility Baubo emphasises Demeter's self-denial. By lifting her skirts Baubo removes the veil from this fecundity, and thus is Demeter reminded of her role-who she is. Baubo acts as Demeter's mirror in that she exposes Demeter to herself ${ }^{104}$. This reminder as to her nature does not shock Demeter back into her role, but rather causes her to laugh.

\footnotetext{
${ }^{104}$ Understanding the importance of dramatised reflections of life is integral to understanding Nietzsche's elaborations of the relationship between the dionysiac and the appolline. We must remember the output of this relationship as the development of Greek Tragedy. It was this theatrical imitation which met with denigration by Socrates in Plato's works. (Although Plato's own use of Dialogue makes him guilty of the very crimes against reality which Socrates would save humankind from.)
} 
Demeter finds Baubo's affectation of fertility laughable because it is only an affectation of the goddess' power. Baubo is an old woman; her body can no longer be used to create life. Baubo can only play at being Demeter, and this play can be nothing more than amusing-it can never, in and of itself, be life-giving. The power of amusing play, however, if not life-giving on its own, certainly becomes life-giving by proxy. By making Demeter laugh, life returns to the world. Demeter's laughter is thus her affirmation of her role-and this affirmation comes through the act of play.

As we have said, Baubo's act of exposure has an obvious relationship with Dionysos and the dionysiac. Specifically, Baubo's raising of her skirts is a direct reflection on the relationship between Apollo and Dionysos. Baubo's lifting of her skirts lifts the veil of dissimulation, the apolline, from Demeter. She reconnects Demeter to the general element of life, the dionysiac, which Demeter is goddess of, through laughter. This is intoxicating laughter and thus further related to an experience of the dionysiac; the boundaries Demeter has placed between herself and her nature are destroyed through $\mathrm{it}^{105}$. Baubo, with her exposure, represents at bottom Nietzsche's deconstruction of the life denying apolline values as understood by Christianity.

${ }^{105}$ The intoxication of laughter and gaiety in general is important for Nietzsche. He aims to elevate laughter, dance and music in his trans-valuation of values. Hence the philosopher's development of a 'gay science.' This elaboration of the 'gay science' is Nietzsche's attempt to overcome his 'devil,' known as the spirit of gravity. (Nietzsche. "The Dancing Song" Thus Spoke Zarathustra. p 219.) 
Although the above allows us to justify Baubo's importance on the grand scale for Nietzsche, it does not appear to have any bearing on our quest to deconstruct the imposed false feminine value. In our elaboration of the present state of woman under the imposed feminine value we travelled the path of love. We must now return to this path in order to follow Nietzsche's deconstruction of the feminine gender. Our task in this second leg is therefore the deconstruction of the value of love using the myth of Baubo. In our previous analysis of Nietzsche's writings on woman's love we found that love for woman begins as a womanly attempt to arouse desire in men; for this reason woman develops love as an idol. But woman has forgotten why she elevated love and thus becomes trapped in her own net. Woman believes in the idol love. This, which amounts to the valuation of love, is the root cause of both the perpetuation of woman's acceptance of the imposition of the feminine and the beginnings of her further perversion under it.

We have stated previously that the primary manifestation of woman's belief in her idol of love coincides with the Christian removal of the erotic from the definition of love. This subtraction of eros from love is our starting point in the deconstruction of the imposed feminine value. The erotic is subtracted from love, according to Nietzsche, as a result of the slave's transformation of the human multiplicity into a duality: the body which is base and the soul which is divine. This transformation develops through dogmatic Christianity and is predicated on the Christian notion of eternal salvation or the 'return' to 'God.' The notion of eternal salvation is the slave's overcoming of his newly created 
master because 'God' himself has no power other than that which is given him by the slave. Explicitly, in preaching the doctrine of eternal salvation of the divine soul the slave is able to become one with 'God,' therefore becoming master himself. Let us here note that the concept of the eternal salvation is a return to 'God' as opposed to a first meeting. Christianity preaches that we were once in complete concert with 'God,' but through our own folly we have fallen away from him. This is the biblical story of Genesis as it elaborates the first couple and the ultimate fall from grace. It is the fall from grace which, according to Christianity, has separated man into body and soul.

In the fall from grace, man's will is separated from 'God's' will. In his separation from 'God' man loses the ultimate control he had over himself while aligned with 'God"106. Specifically, no matter the strength of his will, he cannot overcome the needs of his body. Given that it is the slave's will to be master which leads to the slave revolt in morality and the development of 'God,' this bodily neediness can be seen to directly frustrate the actualization of the slave's will-to-power. Thus, in order to further proclaim himself master, the slave must attempt an impossibility, he must gain mastery over the body. This attempt results in the vilification of the body and all physical needs.

It is impossible, however, for the body and its physical desires to be done away with (at least in any fashion where there is the continued semblance of life). As we have said, unsatisfied and thwarted bodily desires go underground to form

${ }^{106}$ This is not entirely true. Wo/man has no individual control in Paradise. Rather $\mathrm{s} / \mathrm{he}$ is part of the Divine; it is the will of the godhead which is actualised here. There is no control or lack of control in Paradise, there is merely 'God's' will. 
the 'bad conscience ${ }^{107}$.' Sexual desire, as the most uncontrollable of all bodily functions, (we may will ourselves not to eat, but we can not prevent ourselves from becoming aroused) is thus recognised by Christianity as an obvious evil, and eros is pushed into the realm of vice. The erotic bad conscience is manifested through shame-hence the name 'pudenda,' or, organs of shame. We have attempted to overcome our sexual shame by creating (and in the case of womandeifying) the concept of love. In love we have attempted to transform the physical attraction between men and women into a meeting of souls. Although male/female relationships are necessarily predicated on sexual attraction and lust, we attempt to hide this primary drive behind the pretty words of love.

The female body, in particular, has been condemned by all three Abrahamic faiths as the seat of the erotic. Women's bodies, which 'devilishly' arouse 'chaste' men, have historically been castigated as overtly sexual. Christian doctrine attempted to cloak the 'inherent' sexuality of women by providing the chaste example of the Holy Mother. Mary, the perfect mother, is largely asexual. Womanly love, according to Christian doctrine, is that of storge $\bar{e}$ as opposed to eros. Women are always mothers under the veil of Christianity, and never lovers. Baubo's lifting of her skirt automatically destroys the Christian vision of the chaste mother by reconnecting childbirth with sex.

In this 'poisoning of eros ${ }^{108}$,' as Nietzsche terms it, we encounter Baubo's role as deconstructor of the feminine. Woman as defined by the feminine has

\footnotetext{
${ }^{107}$ Nietzsche. "Second Essay: 'Guilt,' 'Bad Conscience,' and the Like" in The Genealogy of Morals. pp57-96.

${ }^{108}$ Nietzsche. Beyond Good and Evil. Aph 168.
} 
adopted the value of love as her own. Because of this adoption she has perpetuated the feminine veil with which man has shrouded her. Thus in order to deconstruct the imposition of the feminine we must deconstruct the value of love. This deconstruction of the value of love involves the removal of the veil of idealised love in order to expose the reality of 'natural' male/female relationships - the reality of the erotic. Idealised love has forced the erotic into shamefulness and thus, the deconstruction of the value of love is a deconstruction of the concept of shame ${ }^{109}$. Bodily shame must be overcome in order to re-insert the erotic into the definition of love. Baubo's shameless lifting of her skirt is the perfect exemplification of this.

How is the veil of shame removed from the erotic in Nietzsche? Let us consider a passage from Thus Spoke Zarathustra which deals particularly with the re-awakening of eros:

One evening Zarathustra walked through a forest with his disciples; and as he sought a well, behold, he came upon a green meadow, silently surrounded by trees and shrubs, and upon it girls were dancing with each other. As soon as the girls recognized Zarathustra they ceased dancing. But Zarathustra walked up to them with a friendly gesture and spoke these words:

'Do not cease dancing, you lovely girls! No killjoy has come to you with evil eyes, no enemy of girls. God's advocate am I before the devil: but the devil is the spirit of gravity. How could I, you lightfooted ones, be an enemy of godlike dances? Or of girls' feet with pretty ankles?

'Indeed, I am a forest and a night of dark trees: but he who is not afraid of my darkness will also find rose slopes under my cypresses. And he will also find the little god whom girls like best: beside the well he lies, still, with his eyes shut. Verily in bright daylight he fell asleep, the sluggard! Did he chase after butterflies too much? Do not be angry with me, you beautiful dancers, if I chastise the little god a bit. He may cry and weep - but he is laughable even when he weeps. And with tears in his eyes he shall ask

${ }^{109}$ Nietzsche. Beyond Good and Evil. Aph 114 and The Gay Science Aph. 71. Aphorism 71, entitled On Female Chastity, is particularly interesting on this point. Here Nietzsche is expressing sympathy and awareness of the incredible paradox nineteenth century women were faced with in regards to love and marriage. Specifically, Nietzsche draws our attention to the agreement that upper class women ought to be kept in the dark concerning all sexual matters only to be shocked by the reality of the erotic in marriage. Nietzsche finishes the aphorism with a few of the only explicitly kind words he writes concerning women, 'in sum, one cannot be too kind about women.' 
you for a dance: a dancing and mocking song on the spirit of gravity, my supreme and most powerful devil, of whom they say that he is 'the master of the world ${ }^{110}$.'

Let us begin our analysis with the dancing girls. The girls have taken themselves to a secluded glen in a forest in order to dance. Because they have removed themselves from all prying eyes we encounter the possibility that what they are doing is forbidden — that these young girls should not be dancing. This is further suggested by their reaction to Zarathustra and his disciples; upon realizing that they have been discovered the girls immediately stop dancing. What in their dancing causes them angst at the possibility of discovery? What is wrong with dancing? According to Nietzsche dance acts as the ultimate connector, a string which binds the disparate aspects of the human multiplicity. Our entire being is engaged by the movement of dance ${ }^{111}$. This engagement is dionysiac and therefore subject to feelings of shame. The girls are afraid of Zarathustra because they are ashamed. Zarathustra seeks to put them at ease by informing them that he shall wake the sleeping Eros. The suggestion being, that by awakening Eros, Zarathustra will justify the girls' erotic nature and overcome their shame.

The erotic awakening of the girls is integral to Nietzsche's goal of the reintroduction of the dionysiac to the world. As we have said Nietzsche's fascination with dance arises from his conviction that dance is the great connector, the dancing individual is, therefore, entirely engaged. All physical and

\footnotetext{
${ }^{110}$ Nietzsche. 'The Dancing Song' in Thus Spoke Zarathustra. pp. 219-220

${ }^{111}$ Nietzsche considers dance to be the highest form of movement. We walk and we run in the hopes that one day we might dance. But, more than this, dance is the highest form of thought for Nietzsche. Books and writings must be able to dance-Nietzsche's primary criticism of his Birth of Tragedy was that it did not dance. He describes his inspiration for parts of Thus Spoke Zarathustra as 'bodily inspiration,' arguing that the creative impulse flows from bodily movement, particularly dance.
} 
mental aspects of the dancer contribute to the dance. This connective aspect of dance destroys the false boundaries the individual creates within him/herself. The dionysiac experience of dance moves beyond this highly individualised and internal connectivity to deconstruct boundaries between individuals and their physical environment. The girls' dancing obviously partakes in this aspect of the dionysiac in that they have succeeded in deconstructing their internal and external individual boundaries. This is exemplified by their ability to dance shamelessly with each other. The girls have not succeeded, however, in consorting with the world around them. Rather, the dancing girls instead of deconstructing the environmental/social boundary have only succeeded in pushing the limen just beyond the confines of their group. This is the boundary between themselves and Zarathustra and his disciples and it is a line the girls are unwilling to cross.

The boundary the girls erect between Zarathustra, his disciples and themselves is defined by sexual identification-male versus female. This sexual boundary is the categorical distinction within the human species. It is the first divider and the primary division. Deconstruction of the sexual boundary is therefore integral to the success of the dionysiac experience ${ }^{12}$. While engaged in their homosocial (homosexual) dance the girls are untainted by shame. The continued sleep of Eros ensures the maintenance of the sexual boundary as the girls remain in the clutches of heterosexual erotic shame. Eros must awake in

${ }^{112}$ The outward licentiousness of the dionysiac festivals of the ancient world attest to this. In The Birth of Tragedy Nietzsche makes clear reference to the overtly sexual behaviour of the festivals to Dionysos - suggesting that the violently sexual experience of these festivals is a leading cause for the divine partnership of Apollo and Dionysos. The dionysiac as it is portrayed in Greek tragedy lacks the wildly untamed sexual behaviour noted in the 'barbarian' cults of Dionysos. 
order for the girls' dancing to fulfill the Nietzschean criterion of dance--the girls' dance must embrace the body erotic.

Although we are aware that the girls' dancing is erotic before Zarathustra awakens Eros, its homo-erotic nature is necessarily exclusionary and, therefore, unsatisfactory. The expression of the homoerotic connects each individual girl to the small female community the dance has created. The homoerotic nature of the girls' dance is solidified by Zarathustra's reaction to the girls and their reaction to him. The girls' homoerotic (homosocial) deconstruction is recognised as restrictive when Zarathustra and his disciples enter their midst. The men's attempt to force their way into the homosocial erotic experience-exemplified here by the role of spectator-causes the girls to become ashamed. This shame arises out of being 'caught' engaging in erotic behaviour-flaunting their erotic nature as opposed to hiding it.

Zarathustra 'awakens' Eros in the small community through his ability of persuasive speech. The tone Zarathustra adopts in speaking to the girls is, however, different from any he has used in his previous exhortations. He adopts a tone specific in its use towards these girls and it is a flirting tone. The moment is striking for us readers. Zarathustra is flirting! He desires these girls. The girls are undeniably aware of their effect on Zarathustra, and are thus aware that their dance is erotic. The girls' awareness of the arousal of Zarathustra and his disciples is manifested by the immediate suspension of the dance. (Perhaps they are a little afraid that Zarathustra and his disciples will defile them.) The girls are not only ashamed of being caught engaging in erotic activity but they are ashamed 
the effect this activity (arousal) has on the men. This is a shame which arises from the sleeping Eros. For, surely, if Eros was awake the girls would embrace the introduction of men into their dance and thus into their group. When Eros is awoken the girls resume their dancing in order to dance with him. Henceforth their dance becomes explicitly erotic (and entirely dionysiac ${ }^{113}$ ); its erotic nature comes forth in the song Zarathustra sings concerning his own erotic relationships ${ }^{114}$.

But what has changed with the awakening of Eros? At first the answer would appear to be nothing - we have simply returned to the first moment of the aphorism. This, however, is not the case. By returning to the dance the girls have overcome their shame with regard to their erotic dancing. Moreover, the girls could not have returned to the dance if Eros had not awoke; this much is clear in Zarathustra's definition of his 'darkness' - his 'libido' ${ }^{15,}$ - of which the girls are afraid. In order to calm the girls in the face of his 'darkness' he must awaken Eros - and thus expose the girls' own 'darkness' in addition to their 'rose slopes.' Zarathustra forces the girls to recognise both his erotic nature and their own.

Thus Zarathustra adopts the role of Baubo with regards to these dancing girls. He lifts his metaphorical skirts by 'awakening' the sleeping Eros; by exposing the girls to his own arousal and subsequently causing the girls to recognise their own. What Zarathustra has hidden under his 'skirts' is revealed in

\footnotetext{
${ }^{113}$ These girls could, arguably, embody the Bacchae for Nietzsche.

${ }^{114}$ In this song we learn of Zarathustra's love affairs with the mytho-allegoric women of Life and Wild Wisdom. We also learn that these two women are in fact one, there is only Life; but Zarathustra is unable to recognise Wild Wisdom as being a mere characterization of Life.

${ }^{115} \mathrm{We}$ are using the word libido here in its first meaning that of psychic/emotional energy derived from biological urges, but we are certainly not discounting the sexual definition either.
} 
the 'dancing and mocking song' he sings to the girls-it is the dionysiac reality. Thus does the song begin with Zarathustra's conversation with the mythoallegoric woman Life. Zarathustra, similar to Baubo with the drawing of Iaachos on her stomach and her exposed pudenda, draws the girls' attention to the aspects of natural life. Storgē is transformed into Eros.

Zarathustra 'exposes' himself to the girls with his waking of Eros and this exposure is in keeping with the notion of 'play' we considered in relation to Baubo's lifting of her skirts. The song he sings is a 'dancing and mocking' song. And similar to Baubo's play leading to Demeter's affirmation of life, Zarathustra's dancing and mocking song, in allowing the girls to continue their dance (or, rather begin a new dance) is the cause of the girls' affirmation of their own erotic nature. Moreover, the girls' affirmation of their erotic nature is in itself an affirmation of life.

Having asserted in Chapter One that the imposition of the feminine value is a manifestation of the linguistic transformation of the creative slave, we must consider how Baubo's exposure acts as a deconstruction of the Christian slave's value-laden language. In order to reach the stage where slavish values can be trans-valued Nietzsche needs to ensure that these undesirable values are discounted to the point of destruction. His method for deconstruction is twofold: firstly, Nietzsche elaborates the need to embrace dualisms; secondly, upon 
acceptance of all dualisms, he exposes the detrimental value system to ridiculethis is exemplified by good spirits. This twofold process succeeds in deconstructing the Christian slave's value system by forcing the linguistic definitions of the slave to turn upon themselves and thus cancel each other out.

The Christian slave's complete separation of the world into 'good' and 'evil' and the concomitant attempted eradication of the 'evil' value has led to the belief that humanity has one nature only. The placement of duality within a single human entity has become a linguistic impossibility. One cannot be both, 'good' and 'evil,' just as a cat cannot be both 'black' and 'white.' By demonstrating duality within a single nature this definitional limitation is overcome-while simultaneously playing on our notions of the ridiculous. Whence we realise the possibility of duality in a single individual the notion of singularity in the individual is destroyed. If we can 'be' more than one thing, then we cannot be 'one' thing - the assumption of our divine driving soul is destroyed by the assertion of our animal nature. Laughter and joy finishes the process begun by the recognition of duality by allowing us to move beyond this stultifying recognition. We are ridiculous in our contrariness, but our ability to find laughter in this ridiculousness belies the success of Nietzsche's 'gay science.'

The myth of Baubo characterises this deconstruction fully. The act of her exposure has Baubo embodying numerous integral and important dualisms. Eros (her exposure of her vulva) versus storge (in the painted face of Iaachos) and eternity (through her mirroring of Demeter) versus temporality (her own nature) are the dualisms strikingly dominant in Baubo's self exposure. Baubo's 
embodiment of these dualisms, however, only goes part way towards their deconstruction. It is not until Demeter laughs at Baubo's ridiculous portrayal of the value system that spring returns. As we have mentioned before, Baubo's embodiment of these dualisms is ridiculous, but in order to overcome Demeter's never-ending sadness, the goddess must recognise the ridiculousness of Baubowhich is, inherently, recognition of her own ridiculousness. Demeter's rollicking laughter overpowers and destroys the weight of her grief.

We encounter the same process in Zarathustra's awakening of Eros. Here Nietzsche christens Christian slavish values; they are Zarathustra's devil, known to us as 'the spirit of gravity.' The spirit of gravity is among the visitors to this secluded glen in the form of erotic shame. By awakening Eros, Zarathustra forces the girls to embrace their dual nature as both erotic animal and high-minded human. The girls' introduction to the dualities of their nature only acts as an overcoming of the weight of shame with Zarathustra's singing of the 'dancing and mocking song' accompanied with the girls' return to dance. In this passage dance fulfills the same function that Demeter's laughter satisfies in the myth of Baubo.

We have deconstructed the feminine value as it is explicitly exemplified by the feminine idealisation of love by exposing feminine love to its multi-faceted nature. Here the dualities of love (particularly the motherly storgē and the sexual eros) have clashed and deconstructed as a result of Nietzsche's joyful science. Having cleared the air for reconstruction through our deconstruction we are now able to move to the final stage of our journey. Leaving Baubo with her skirt in the air we now travel towards Ariadne. 


\section{Chapter Four \\ Autonomous 'woman': silent Ariadne}

A labyrinthian man never seeks the truth but always only his Ariadne-whatever he may tell us.

Nietzsche. Werke: Kritische Studienausgabe ${ }^{116}$

We have arrived at the final stage of our journey. Having travelled through woman's 'present' using the myth of Echo and Narcissus and undergone the deconstruction of the feminine gender imposition of this 'present' using the myth of Baubo, we are now ready to consider Nietzsche's highest hope for woman. As in the last two legs of our journey we shall embark on this final stage by considering our map of mythology. In this final stage we shall elaborate Nietzsche's trans-valuation of values and consider how this trans-valuation affects the value of the feminine. Here we shall consider Nietzsche's new values by retelling the myth of Ariadne and Dionysos ${ }^{117}$.

\footnotetext{
${ }^{116}$ Friedrich Nietzsche. "Notes: Nov. 1882-Feb. 18834 [55]" in Werke: Kritische Studienausgabe, X, p. 125. Accessed on-line on 01 July 05. Available at http://www.geocities.com/thenietzschechannel.

${ }^{117}$ Adapted from Thomas Bulfinch. "Theseus" and "Ariadne" in The Age of Fable in Bulfinch's Mythology. Toronto: Random House, 1998. pp 142-145 and p 154.
} 
Ariadne loved Theseus. Theseus loved Ariadne, but not well enough. She saved him from the Minotaur by giving him a sword (with which to slay the Minotaur) and a spool of thread (with which to best Daedelus' labyrinth). In return for her gifts Ariadne asked Theseus to make her his wife, taking her with him when he escaped. Following Theseus' success in the labyrinth (where he made good use of Ariadne's gifts) the lovers left Crete turning their ships toward Theseus' home of Athens. Along the way, the ship stopped on the island of Naxos. Here Ariadne fell asleep. When she awoke she was alone-Theseus having set sail once more while she slept. Ariadne was heartbroken, but her pain was soon eased by Aphrodite who promised her an immortal lover in the stead of the mortal one she had lost. Dionysos arrived on Naxos, his favourite island, and fell in love with Ariadne. He made her his immortal wife and together they had many children.

Our use of this myth to describe Nietzsche's trans-valuation of values comes from Nietzsche directly. Nietzsche's choice of this myth comes from its relation to Dionysos. As we saw in our consideration of the myth of Baubo, Nietzsche's trans-valuation of values is rightly termed a dionysiac trans-valuation. We have said this because of the philosopher's assertion that modernity, as cloaked by the Apollo's dream shroud, suffers a disconnect from reality as it is provided by Dionysos. More explicitly, modern humanity is impaired by the growth of socratism as it is exemplified by Christianity. Nietzsche's solution to this, humanity's 'problem,' is the re-introduction and re-emphasis of the role of 
the dionysiac. Ariadne's primary importance within this framework therefore comes from her relationship with Dionysos.

We have already elaborated on the role of Dionysos and the dionysiac in Nietzsche's writing. Essentially we have said that Dionysos is integral to Nietzsche's task because of the philosopher's assertion that the dionysiac experience reconnects humanity with itself and nature. Or, that humanity must awake from its apolline dream. But this tells us very little about Ariadne, what is her role in the trans-valuation of values? Although Nietzsche has written extensively on the role of Dionysos and the dionysiac, he has left the character of Ariadne exceptionally under-defined. She is mentioned a mere four times by name in the complete corpus of his published works. All mentions and referrals to Ariadne are, however, ultimately linked to her role in the myth of Ariadne and Dionysos. We must therefore take a closer look at this story as we have elaborated it above.

How does Ariadne come to be Dionysos' lover and wife? The answer returns us to the concept which has carried us through out our journey: destructive love. However, although Ariadne's love for Theseus is reminiscent of Echo's wasting love for Narcissus in that it is characterised by the dissatisfaction of desire, the results are drastically and significantly different. Unlike Echo, Ariadne's unsatisfied desire does not become all-consuming. Ariadne will survive the loss of Theseus. Indeed, only by losing him can Ariadne become who she is for Nietzsche. The myth of Ariadne and Dionysos begins where the myth 
of Theseus and Ariadne ends. We must begin our consideration of the myth, therefore, with Theseus leaving Ariadne asleep on Naxos.

The differentiation between the state of being asleep and the state of being awake is once again important. Because Theseus leaves her while she sleeps we must consider the possibility that, in fact, Ariadne's relationship with him is nothing more than a dream. She awakens to the reality that she is alone. This is of obvious comparison to Nietzsche's notion of idealised love, particularly as we have related it through the myth of Echo and Narcissus. Ariadne idealised her love for Theseus, and this is the state of her dreaming sleep. When she awakens to realise she has been left alone the dream ends and with it, her idolisation of love. She is newly awakened to the reality of her situation which places into perspective her dreaming love; or, rather, her dream has been exposed as such. Ariadne awakens whereas Echo is unable to.

Into this state of new awareness Dionysos makes his entrance. Or, rather, for Nietzsche, Ariadne must awake in order for Dionysos to gain entrance. Given Nietzsche's elaborations on the partnership between Apollo and Dionysos, it would seem that Ariadne begins the myth under the veil of the sublime dream (characterised by her love for Theseus) which is the province of Apollo. When she awakens, she awakens to the reality of loneliness-the man whom she believed herself to love (and whom she believed loved her) has left her. She awakens to realise that she is radically separated from her surroundings. This separation is exemplified by her environmental disconnect. She does not know Naxos and is very far from home. She awakens to realise that her dream of love 
is false. This leaves her in a state where it is 'unsafe' to simply accept the experiential (existential) reality of anything but her sadness. Her new alertness is better described as anomie and nihilism than the intoxicating experience of the dionysiac.

The instability of Ariadne's situation when first on Naxos creates a quality of danger. All that she has understood (or believed herself to understand) has been taken from her. Ariadne is in the precarious position of recognising her beliefs as unfounded and wrong. She must pass through this phase, she must survive the black hole of nihilism, in order to recognise and accept redemption in the form of the dionysiac experience. For Ariadne the dream has ended, Baubo has lifted her skirt and exposed herself to the world. The newly alert Ariadne is thus prepared for her meeting with Dionysos—-for if she did not awake she would be unable to see the god from behind Apollo's sublime dream.

It becomes clear to us that, Ariadne is the model woman for Nietzsche's conception of the value of the feminine. Ariadne begins as Echo. She is defined and described only in terms of her love for Theseus. It is this love which pushes Ariadne into action; here exemplified by the gifts she gives to Theseus. As Echo attempted to overcome her objectivity by adopting the masculine role of lover so too does Ariadne. But, unlike Echo, Ariadne undergoes deconstruction as we have elaborated it in our analysis of the myth of Baubo. This only becomes obvious through Nietzsche's description of Ariadne by Dionysos. 
In "Ariadne's Lament" Nietzsche describes Ariadne's meeting with Dionysos as one of particular struggle. Nietzsche, speaking through Ariadne, tells us that he is both attracted and repulsed by Dionysos ${ }^{118}$. The importance of this poem, however, does not lie in the development of this struggle but in the final stanza of the work; whereupon Dionysos speaks to Ariadne/Nietzsche. To whit; "Be clever, Ariadne!.../You have little ears; you have my ears:/Put a clever word in them!-/Must one not first hate oneself, in order to/ love oneself?.../I am your labyrinth... ${ }^{19 "}$ Ariadne's internal struggle (which is actually Nietzsche's internal struggle) characterises Baubo's juxtaposition of dualisms as deconstruction. In this specific instance, we have the two characters themselves juxtaposed within Nietzsche the philosopher. The secondary criteria we listed as definitive of Baubo's deconstruction is characterised in the final stanza of the poem by Dionysos' mocking of Ariadne. By making light of Ariadne/Nietzsche Dionysos negates the weight of the previous struggle. Or, rather, following this mockery the struggle exists no more.

\footnotetext{
${ }^{118}$ There is some complexity as to who is actually speaking in this poem. The majority of the piece had been published in Book IV of Thus Spoke Zarathustra, where the poem was connected with a 'magician' Zarathustra came across. (Ostensibly missing from this publication is the important final stanza. It is arguable that it is this stanza which relates to Ariadne as opposed to the entirety of the poem.) Although Nietzsche's title of the poem references Ariadne's struggle with the god, it is apparent that Nietzsche is referring to his own struggle in accepting Dionysos as his god. This poem is therefore referencing Nietzsche's self-transformation as Ariadne. The use of Ariadne to describe this is in keeping with Nietzsche's use of the feminine position to describe himself and his philosophical development. It would be better to describe the body of this poem as the internal between Nietzsche as Ariadne (his philosophical feminine side) and Nietzsche as Dionysos (his philosophical masculine).

${ }^{119}$ Nietzsche. "Ariadne's Lament" in Dionysus-Dithyrambs. Trans. The Nietzsche Channel. Accessed online 15 July 2005 . Available at http://www.geocities.com/thenietzschechannel/dd.htm\#7 .
} 
For Nietzsche, Ariadne is above all the partner of Dionysos. It would be incorrect of us to attempt to consider her role outside of this partnership. Given this, let us consider the immortal god and his wife.

'Under certain circumstances I love mankind'-alluding to Ariadne, who was present-'Man is to me an agreeable, brave, ingenious animal without equal on earth, he knows how to make his way through every labyrinth. I like him: I often ponder how I might advance him and make him stronger, more evil and more profound than he is.''Stronger, more evil and more profound?' I asked in alarm. 'Yes,' he repeated, 'stronger, more evil and more profound; also more beautiful' —and as he said that the tempter god smiled his halcyon smile, as though he had just paid a charming compliment. Here one will also see that this divinity is lacking in shame-; and there is in general good reason to suppose that in several respects the gods could all benefit from instruction by us human beings. We human beings are-more humane... ${ }^{120}$

In this aphorism Nietzsche clearly dictates Dionysos' role in Nietzsche's teaching; namely, that of 'improver' of mankind. Nietzsche's Dionysos would have man become 'stronger, more evil, more profound and more beautiful.' This is in keeping with the philosopher's description of the dionysiac. By seeking to improve humanity in these four areas, Nietzsche, through Dionysos, hopes to reconnect the human with the animal. But, beyond this, he seeks to make humanity more than it is at present. Nietzsche would have us become more than we are-more than simply human. It goes unspoken, but Nietzsche is here alluding to his doctrine of the superman ${ }^{121}$.

Nietzsche develops the idea (the goal) of the superman most completely in Thus Spoke Zarathustra. Drawing on his understanding of Darwin's theory of evolution, the doctrine of the superman asks us to question the anthropomorphic assertion that the current manifestation of the human species is the highest stage of evolution. Effectively, Nietzsche asks us to question the assertion that the

\footnotetext{
${ }^{120}$ Nietzsche. Beyond Good and Evil. Aph 295.

${ }^{121}$ Nietzsche. 'Upon the Blessed Isles' in Thus Spoke Zarathustra. 197-200.
} 
universe has reached its teleological conclusion with the introduction of the species Homo sapiens. In opposition to this ascription of a human telos Nietzsche teaches that modern humanity is merely a step in the evolutionary cycle; a bridge, as he terms it, to the superman ${ }^{122}$.

Humanity's ability to overcome the confines of the species is suggested in the parting line of the above quoted aphorism. Although this first appears to be a denigration of Dionysos' godly lack of shame, we must consider it in the greater context of Nietzsche's works - specifically its relation to Nietzsche's conception of the 'human, all-too-human.' According to Nietzsche the human being has been tamed — we have made ourselves into herd animals. Humanity has developed all the placidity and resignation of cattle with none of the animal recognition therein associated $^{123}$. The human transformation into herd animal comes through the species' initial acceptance and subsequent manipulation of the slave's 'good/evil' value dichotomy. The success of this value distinction (which relies on the slave's ability to justify the value 'good' as an inversion of the master's 'bad') has been overly convincing, notably to the detriment of its opposite 'evil' value.

Humanity's unchallenged acceptance of the slavish 'good' has thus led to the denigration and attempted destruction of the slave's 'evil' values. This is a foiled attempt to overcome humanity's natural, if distasteful, 'evil' instincts. The result is a human definition wherein the possibility of 'evil' becomes unthinkable; but not, however, impossible. The over-emphasis on 'good' values causes the human animal to become a 'reverse cripple'-possessing too much of one value

\footnotetext{
${ }^{122}$ It is interesting to note that Nietzsche does not, in his theory of the superman, deny or discount the notion that there is a telos to the universe. Rather, Nietzsche simply moves the endpoint.

${ }^{123}$ Nietzsche 'Why I am a destiny' in Beyond Good and Evil. Aph. 4
} 
and not enough of the other ${ }^{124}$. As Nietzsche defines it we become 'fixed' in our human-ness (humaneness): we become too human. As opposed to overcoming the dualism of 'good/evil' by overemphasising 'good' humanity only becomes further entrenched within the slave's value dichotomy. As we considered in the previous chapter, in order to overcome duality one must first embrace all dualities ${ }^{125}$. By embracing one's dualisms (recognising one's capability of 'evil' in addition to 'good') one can move beyond the constraints of either value and therefore beyond the dualism itself. Moreover, acceptance of the 'evil' within our nature allows us to destroy the 'bad conscience' which has been cultivated by our failed destruction of the slave's 'evil' values.

But what is Ariadne's role in this? Nietzsche, as Dionysos, begins the aphorism by stating that under certain circumstances he loves humanity, and we are told that this love for humanity comes as a result of his love for Ariadne. Or, rather, Ariadne is the specific circumstance whereby Dionysos loves mankind. Apart from his love for Ariadne, Dionysos merely likes mankind. The characteristics of man which result in Dionysos' 'like' for him are also, oddly, related to Ariadne. They are the characteristics of Theseus as he displays them in his meeting with Ariadne. This is made explicit by Nietzsche's comment, by way of Dionysos, that man can find his way out of every labyrinth. This reference to man's 'navigational' ability is of particular interest to us given our knowledge of the myth of Theseus and Ariadne. We know that Theseus would not have succeeded in his attempt to best both labyrinth and Minotaur if it were not for

\footnotetext{
${ }^{124}$ Nietzsche "On Redemption" in Thus Spoke Zarathustra. pp. 249-254.

${ }^{125}$ Chapter Three, pp 73-73.
} 
Ariadne. Although Theseus possesses the characteristics of bravery, agreeability, etc. his success is contingent on Ariadne's gifts. Theseus' relationship with Ariadne is, therefore, the precondition of his general success. Man's relationship with Nietzsche's Dionysos is therefore dependant on Ariadne. Nietzsche's Dionysos is first drawn to humanity as a result of his love of the mortal woman Ariadne, but the god becomes engaged in the world of men by way of man's ingenuity and cleverness as they are showcased by way of Ariadne's gifts to Theseus. This is further established if we consider the myth of Ariadne as a bridge between two others: the myth of Theseus, and the myth of Dionysos. She is the link between Theseus, the man, and Dionysos, the god. It is through Ariadne that Dionysos develops his interest in mankind-which we should understand as mankind and not the entirety of humanity.

But what is Ariadne's role other than link between man and god? We still don't know who she is. Let us re-examine what we have said about Dionysos. He is the god of the terrible truth, of frenzied reality, of intoxication and ecstasy. When we experience him in all his glory he causes our own insanity. He must therefore be tempered through a veil of unreality, of dream. Nietzsche is acutely aware of the importance of this tempering of the dionysiac. It is his task to reconnect humanity to the dionysiac experience but only as it is characterised by Greek tragedy ${ }^{126}$. Because of this, we realise that Nietzsche must support some maintenance of the apolline. If Nietzsche has chosen to make Dionysos his god, we must ask ourselves, where is the philosopher's Apollo? Is it simply that Nietzsche hopes to re-inject the dionysiac into our already apolline world? This is

${ }^{126}$ Nietzsche would not have us become bacchanal. 
an 'easier' task, and a less destructive one. But it doesn't 'fit' with Nietzsche's notion of the trans-valuation of values. The apolline value dichotomy we presently ascribe to must be destroyed, overthrown, renamed, and re-valuedwithout this there is no 'trans-valuation,' merely the introduction of new values. The introduction of new values into our present value system is not enough for Nietzsche because of the irrevocable perversion of the apolline dream by the Christian value dichotomy. Merely 'injecting' the dionysiac into our present value system would be simply unsuccessful—-the dream veil of Christianity would not 'tolerate' the dionysiac. There can be no divine partnership between the Christian 'God' and Dionysos ${ }^{127}$. Because Nietzsche is aware that merely injecting the dionysiac into our modern world would be a colossal failure, we must accept the possibility that in addition to elevating Dionysos, Nietzsche seeks to create a new 'Apollo' _ or at least some semblance of the apolline. This is the role Nietzsche has carved out for Ariadne.

The essence of woman for Nietzsche is unfathomable. Woman maintains her ambiguity through adornment. Her costuming ability allows her to wear the male created values of the feminine. This genius for the 'veil' or 'mask' makes her an ideal candidate for Nietzsche's rebalancing of the world. She is able to 'veil' the terrors of her godly husband, thus allowing mankind to partake in the dionysiac in a life-affirming and creative way. As a manifestation of the apolline, Ariadne is the bridge between Theseus and Dionysos, or rather; woman forms the

127 'I am the Lord your God...you shall have no other gods before me. You shall not make for yourself an idol, whether in the form of anything that is in heaven above, or that is on the earth beneath, or that is in the water under the earth. You shall not bow down to them or worship them; for I the Lord your God am a jealous God...' (Exodus. 20:2-6) 
bridge between man and god. Without her 'masks' to cover her divine husband for man, man would be unable to bear the sight of Dionysos-nihilism would rule. Dionysos must partner with Ariadne, who in her wakened state is able to bear/see Dionysos, in order to allow man to partake in the redemptive dionysiac.

Ariadne's ability to bear the sight of Dionysos comes from her ability to veil and mask herself. She has, moreover, survived her own experience of nihilism and anomie ${ }^{128}$. With her marriage to Dionysos she is given a new goal which asserts her overcoming of both of these. Ariadne is, in Nietzsche's words; 'the answer to such a dithyramb of solar solitude in the light ${ }^{129}$.' Ariadne, as manifestation of the apolline, succeeds in 'stamping' the dionysiac horror of becoming with being ${ }^{130}$. In Ariadne the ugly reality of the world and the dissembling dream of the eternal world collapse into a single entity. Ariadne's role as bridge prevents humanity from wallowing in Dionysos' horrid and unattractive natural reality and keeps man from becoming entrenched in Apollo's beautiful but useless dream. The collapse of being into becoming through the partnership of Ariadne and Dionysos overcomes the limitations of the realities embodied by the lovers' characteristics. In the service of the affirmation of life Nietzsche has us beautify the natural state of becoming by stamping it with an eternal process-this is his eternal return of the same.

Through Ariadne, Nietzsche's Dionysos communicates with man. This is the primary reason why she must be present in the above quote taken from Nietzsche's 'conversation' with the god. Because she is human, made immortal

\footnotetext{
${ }^{128}$ See footnote 118 .

${ }^{129}$ Nietzsche. 'Thus Spoke Zarathustra' in Ecce Homo. Aph. 8.

${ }^{130}$ Nietzsche. The Birth of Tragedy. Aph. 3.
} 
through her marriage to Dionysos, she lives between the world of the gods and humanity. She is a metaphor: both in the original Greek sense as a carrying over, she carries the dionysiac to mankind; and in the linguistic sense, she allows the unspeakable to speak. This is why Dionysos' speech refers only to mankind, woman's role is different, absolutely, from man's. Through Ariadne, Dionysos is able to comment on mankind and on the state of the world. Nietzsche particularly draws our attention to this in the aphorism entitled 'Beautiful and Ugly' in his Twilight of the Idols:

...-Is the world really beautified, just because man thinks it is? Man has humanised it; that is all. But nothing, nothing whatever warrants us in supposing that it is just man who furnishes the model of the beautiful. Who knows how he appears in the eyes of a higher judge of taste? Perhaps risky? perhaps even entertaining? perhaps a little arbitrary?... 'Oh divine Dionysos, why dost thou pull mine ears?' asked Ariadne once of her philosophic lover, in one of the celebrated dialogues at Naxos. 'I found a sort of humour in thine ears, Ariadne: why are they not longer? ${ }^{131}$

But this only elaborates Ariadne's role in Dionysos' relationship with man, it tells us very little about her own relationship with the god. Above all else they are lovers and, as Nietzsche's 'ultimate' new gods, their love relationship is the paragon of all male/female relationships. What, then, does their love dictate for male/female love affairs? Because Nietzsche's trans-valuation of values is, at bottom, an attempt to re-connect humanity with nature, and thus human-kind with their nature, Nietzschean love must be accordingly natural. Nietzschean love is "...translated back into nature!" meaning (to continue the quote) "Not the love of a 'higher virgin'! No Senta-sentimentality! But love as fatum, as fatality, cynical, innocent, cruel-and precisely in this a piece of nature! That love which is war in

${ }^{131}$ Nietzsche. 'Roving Expeditions of an Inopportune Philosopher' in Twilight of the Idols. Aph. 19 (Emphasis Nietzsche's own.) 
its means, and at bottom the deadly hatred of the sexes ${ }^{132}$ !" This is a radically different definition of love than the manifestation of 'selflessness' which presently predominates.

In order to understand what this definition means for the practice of love we must understand Nietzsche's notion of war-more specifically the philosopher's conception of positive envy in friendship/enmity to understand this quote. Friendship must be 'positive' for Nietzsche, in that it must lead to the development - the self-overcoming - of the individual and the friend. But this does not mean that a positive friendship involves the values of goodness. Rather, for Nietzsche, in order to be a good friend one must be a good enemy ${ }^{133}$. The 'activity' of enmity - as a striving against others-translates into a striving against oneself. This is particularly achieved through the elevation of envy. We must seek to have strong enemies/friends of whom we can be envious. But our envy must become an active envy. Active envy coupled with the development of friendship/enmity leads to perpetual striving and continual self-overcoming. The continual clash between individuals prescribed here requires a state of constant preparation and alertness. By suggesting humanity live in what amounts to a perpetual state of war, Nietzsche aims to overcome the complacency of modernity's decadent nihilism. This is a return to Greek agon as Nietzsche understands it $^{134}$. We must become agonistic warriors in order to ensure we do not remain tractable herd animals. Nietzsche would have us reach to ever greater

\footnotetext{
${ }^{132}$ Nietzsche. The Case of Wagner. Trans. Walter Kaufmann. Amended by the Nietzsche Channel. Accessed online 15 July 2005. Available at http://www.geocities.com/thenietzschechannel/search.htm. Aph. 2.

${ }^{133}$ Nietzsche. 'On the Tarantulas' in Thus Spoke Zarathustra. p214

${ }^{134}$ Nietzsche. Homer's Contest.
} 
summits in our ability (he would have us actually know, and attempt to overcome, our limits) as opposed to sleeping through life in order to die comfortably.

The elevation of the Greek contest has an obvious ramification on the relationship between Ariadne and Dionysos, and on all love relationships in general. Nietzsche's claim that natural love affirms the hatred between the sexes suggests that heterosexual love partnerships, in addition to homosocial (and homosexual) relationships, are essentially agonistic. Effectively, male/female love relationships are predicated on sexual agon as it is characterised by men and women striving against each other in the hopes of self overcoming. Nietzsche's affirmation of love as sexual agon develops from his primary assertion that sexual difference extends beyond the biological. According to the philosopher, fundamental, if inexplicable, differences consummately divide the sexes. This absolute difference causes inter-sexual hatred which is transformed creatively through sexual contest. This is a hate which arises out of love and is, as a result, reminiscent of our initial descriptions of Nietzsche's definition of love. On recognising that the opposite sex is radically different from our own we seek to 'destroy' it. This desired 'destruction' comes as a result of the realisation that we can not transform the other into ourselves. In the sexual contest known as love, man and woman attempt to best one another and thus maintain/create a useful relationship where it would otherwise be impossible to satisfy the disparate desires of both sexes. Sexual agon must also be understood in erotic terms, as the love which drives the contest is necessarily erotic. In its most physical manifestation the battlefield of the sexes is the act of sex. The 'violence' of 
coitus $^{135}$, in which each sex seeks to consume or destroy their partner, becomes ultimately productive with conception.

Sexual agon is also defined by Nietzsche at the level of the individual in the battle between our 'feminine' aspects and our 'masculine.' Nietzsche is explicit in defining himself in feminine terms in addition to masculine. He gives 'birth' to his philosophy, and describes its development as a period of gestation ${ }^{136}$. Sexual agon at the individual level results in the complete deconstruction of gender as we understand it. As in the case with all stereotypes, when placed in direct opposition they are cancelled out. The result of this is an individual beyond the definition of gender valuation-Nietzsche herein allows for the possible development of autonomy.

Autonomy is the individual's highest hope in terms of Nietzsche's transvaluation. Nietzsche argues that it is impossible for the individual (or the race) to be completely free of all mastery, rather the individual has the option of choosing his/her master. The best possibility, according to Nietzsche, is to become master of oneself and therein fulfill the definitional criterion of 'autonomy.' By overcoming both external and internal gender values Nietzsche allows for individual definition within the autonomous framework.

The possibility of autonomy is inherent to Nietzsche's description of Ariadne. She is, as we stated earlier, under-defined. Whereas we initially understood this under-defintion as a hindrance to discovering who Ariadne is

\footnotetext{
${ }^{135}$ Violence in the sexual act is generally linked to erotic transgression, as in the writings of the Marquis de Sade and Leopold von Sacher Masoch (the two halves of the term sado-masochist) forming the bulkhead of this theory.

${ }^{136}$ Nietzsche's use of the pregnancy metaphor has also driven the opinion espoused by some scholars that Nietzsche was in fact a homosexual.
} 
outside of her partnership with man (Theseus) or god (Dionysos) it now becomes clear (in concert with the development of Nietzschean autonomy) that this underdefinition is Nietzsche's trans-valuation of the feminine value. Woman as Ariadne must be under-defined in order for Nietzsche's trans-valuation to have the possibility of success. There are two reasons for this. Firstly, Nietzsche cannot define who woman is as this would essentially transfer responsibility for gynocentric definition from one outside master (masculine slave morality as defined by Christianity) to another (Nietzsche). This would fundamentally discount Nietzsche's task as we have elaborated it. Secondly, because Nietzsche considers the development of individual excellence in terms of agonistic competition which is necessarily predicated on power 'equality ${ }^{137}$, characterised by absolute difference, any suggestion on Nietzsche's part as to who 'woman' is would presuppose the maintenance of a secondary power position for her and negate her absolute difference. Nietzsche's under-definition of woman as Aridane allows for the possibility of self-definition and, subsequently, autonomy. Moreover, it is Nietzsche's expectation that this opportunity will result in new female definition outside of the purview of the past male enforced definition.

With this realisation our journey comes to an abrupt end. Nietzsche can carry us no further. We are now left with possibilities as opposed to outcomes. Nietzsche cannot define the trans-valuation of woman as he does not have the words. Having carried the trans-valuation thus far Nietzsche leaves the discussion

${ }^{137}$ This does not refer to democratic equality, but rather to the fact that neither participant can be beholden to the other. 
to allow those better equipped (women) to finish it. Whether or not the female sex has risen to this task remains to be seen. 


\section{CONCLUSION}

The androgynisation of the species

New Struggles. - After Buddha was dead, his shadow was still shown for centuries in a cave- a tremendous, gruesome shadow. God is dead; but given the way of men there may still be caves for thousands of years in which his shadow will be shown.-And we - we still have to vanquish his shadow too ${ }^{138}$.

Having completed our journey of Nietzsche's trans-valuation of gynocentric truth what remains is our consideration of the success of this transvaluation. In order to address this we must consider where we in the twenty-first century 'are' in relation to Nietzsche's trans-valuation. Effectively, we must ask ourselves if we have risen to the task Nietzsche has set for us.

The world has become nothing if not more frenetic since Nietzsche's departure from it. We still speak of 'God,' although his nature has become ever more malleable as each religious sect capitalises on a different aspect of their 'Lord.' 'God' remains the ultimate justification, however, he is 'cheapened' by the causes he is called on to justify. Our cheapening of 'God' is undeniably worse than our murder of him. The manipulators of 'God' realise that the power of his name remains although his substance has been destroyed. These puppet masters exhume the corpse of 'God' in order to display the movement of his shadow on

${ }^{138}$ Nietzsche The Gay Science. Aph. 108. 
the walls of society, movement which they thereby use to justify their social manipulation. And science, the murderer of 'God,' in proclaiming itself the 'ultimate' truth has become undeniably perverse. We rarely speak of science in the service of life (the only logical aim for the discipline), rather, we are regularly bombarded by arguments articulating the importance of supporting science for the 'sake' of science. Nietzsche's diagnosis of decadent nihilism in the nineteenth century has become pandemic in the twenty-first.

'Woman' by no means emerges unscathed from the continuation of this epidemic. Her perversion under false gender identification has reached schizophrenic proportions. Of greater cause for concern is the popular (although almost exclusively Western) opinion that 'woman' is 'emancipated.' The imposition of the false feminine gender has become increasingly insidious. Small transformations within the definition of the feminine have left both men and women convinced that 'woman' has assuredly changed. For the most part it is assumed that this 'change' is for the better-the suggestion being that woman has become a participant in the world drama.

A result of the repercussions of first and second wave feminisms, the small tweakings of the feminine definition of the past century are visible in a variety of examples ${ }^{139}$. To keep within the vocabulary we have already created for ourselves, however, the change in 'woman' associated with the 'sexual revolution' is most fitting. Arguably arising out of changes in reproductive technology (specifically the birth-control pill) the 'sexual revolution' of the 1960's-70's opened the linguistic sexual gate. The explicit sexualisation of

\footnotetext{
${ }^{139}$ The suffragette movement and equal opportunity within the workplace are two such examples.
} 
language lead to transformations in everyday sexual practice ${ }^{140}$. By opening the doors of sexualised conversation we encounter the possibility that we begin to meet Nietzsche's criteria for the trans-valuation of values. Specifically, we could suggest that the sexual revolution marks the beginning of the deconstruction of the values which spawned our present decadent nihilism. Or, within the vocabulary of our previous journey, the sexualisation of conversation introduces the exposing spirit of Baubo and thus begins deconstruction of our life-denying values by elucidating our dualisms. Quick consideration of the ramifications and results of the sexual revolution show that this is not the case.

When we began our journey we discovered that feminine love had been divided into the (ridiculous) dichotomy of 'woman as mother' or 'woman as virgin;' with the two types (impossibly) collapsing in Mary, the 'Mother of God' the 'paragon' of feminine perfection. This dichotomy comes under attack during the sexual revolution, but not as a dualism. The sexualising of discourse resulted in a frontal attack on 'woman as virgin.' But, as opposed to deconstructing this absurd dualism, the sexual revolution replaced 'woman as virgin' with 'woman as whore.' Effectively, we have thrown over Mary, 'Mother of God' in favour of Mary Magdalen.

The replacement of 'woman as virgin' with 'woman as whore' results in an unsuccessful deconstruction because the dualism in its original form ('woman as mother' versus 'woman as virgin') has not been addressed. There has been no clash within the concepts of the dichotomy itself, rather one value has been

${ }^{140}$ It has been argued that the 'sexual revolution' is nothing quite so spectacular or revolutionary. Rather, the normal ebb and flow of human sexuality allows for periods of prudishness followed by periods of abandonment. 
subsequently replaced by its linguistic opposite. This does not transform the initial dichotomy in any meaningful way. The dualism is not overcome, rather, one concept has decreased in value as the value of the other has risen. This is a simple transition of emphasis rather than the required conceptual clash of dualism. Emphasis transferral does not move 'woman' beyond the dichotomy of 'mother' versus 'virgin,' but instead provides this same dichotomy with a new face. The result of this is the further entrenchment of 'woman' within the dichotomy.

'Woman' becomes further entrenched (and, therefore, further perverted) within her false gender as a result of the sexual revolution because of the assumption that the emphasis transferral within the dichotomy leads to 'real' change. The new found 'freedom' of the female sex (described under the sexual revolution by the ability to speak of sex and the concomitant rise in sexual partners for women) is taken by both women and men to signify her autonomous expression of herself. The actual face of this supposed freedom is the masculinisation of woman. 'Woman' is masculinised by the sexual revolution in the way that Echo is masculinised by her adoption of the role of lover. Her movement away from 'virgin' to 'whore' does not lead to the presumed 'erotic awakening,' but is rather a loss of her 'mystery.' In this loss of mystery 'woman' loses power over herself and over men.

The masculinisation of 'woman' in the nineteenth and twentieth centuries meets with an intriguing concomitant movement in men. Specifically, as 'woman' moves towards the 'masculine,' 'man' moves towards the 'feminine ${ }^{141}$.'

141 This is, of course, the false feminine gender; because, it remains unfortunately the only expression of 'femininity' in society. 
This occurs as desire is rebalanced between the sexes. Or, rather, as woman becomes more 'masculine' the characteristics she desires in man become 'feminine.' This results, of course, in a concurrent movement in man. (As he adopts newly desired 'feminine' characteristics, he in turn desires 'masculine' traits in woman.) Gender obfuscation therefore has become a self-perpetuating machine steadily moving both sexes towards androgyny ${ }^{142}$.

Although it would first appear that the collapse of the sexes into a single androgynous entity epitomises Nietzsche's trans-valuation of all values (i.e. the overcoming of the gender dualism), this is in fact radically incorrect. The androgynisation of the population is a characteristic of Nietzsche's greatest fearthe last man. The removal of the chaos of difference from the human species leads to the advancement of the weakest and the descent of the greatest to a midrange meeting point. The lowest (essentially those most deficient in peculiarly human characteristics) are positionally raised as the bar of social acceptability descends in order to accommodate all. Conversely, the highest are prevented from achieving excellence in order to maintain the mediocre social order. The steady advance/descent towards mediocrity breeds unavoidable stasis in an environment where life incapable of change becomes 'obsolete.' Or, in the case of the human species, the development of stasis within the species presupposes the obsolescence of humanity qua humanity.

${ }^{142}$ The best example of the general androgynisation of the population is given in the scientific community's 'discovery' of differences between the sexes. Consider, for example, the November 2005 Paul Irwing and Richard Lynn article in The British Journal of Psychology entitled "Sex Differences in means and variability on the progressive matrices in university students: a metaanalysis" 
It is clear how the androgynisation of the species feeds the development of Nietzsche's 'last men.' The separation into two sexes has psychological logic in addition to biological, with both cases resulting in 'progeneration.' The psychological offspring of the partnership between male and female has no better example than Nietzsche himself $f^{143}$. Specifically, the androgynisation of the species leads to the stultifying of physical and mental creation.

Approximately two hundred years after Nietzsche's diagnosis of decadent nihilism, society still suffers from this disease. More terrifying, the symptoms of nihilism have worsened. Yet, we are now less aware of the ravages of our disease than we were in the nineteenth century. Always ahead of his time, Nietzsche accounts for the continued festering of our disease ridden society. As the quote which heads this chapter blatantly states, we may have killed 'God,' but we have yet to vanquish his 'shadow.' Or, although the centre to which the values of slave morality were tied has perished we must still succeed in destroying the values themselves. In other words, we have not yet begun to deconstruct the 'good' and 'evil' of the slave, and, thus, we have yet to begin to deconstruct the value of 'gender' in society.

The destruction of the 'shadow of God' is more difficult than the initial murder of the deity. As all shadows, the 'shadow of God' is only visible in certain lights, at certain times of the 'day.' We, therefore, have difficulty in recognising, and thus deconstructing, the 'shadow of God.' What is clear is that

${ }^{143}$ Nietzsche's ability to recognise both male and female aspect within himself led to his philosophy. 
the time has come for Nietzsche's free spirits to wield their hammers. If we cannot vanquish the shadows of 'God', let us at least destroy the caves in which they still show. 


\section{Bibliography}

The Holy Bible. New Standard Revised Version, Catholic Edition. Nashville.

Anderson, Nicole. "Ethical Possibilities of the Subject as Play" The Journal of Nietzsche Studies 26 (2003) 79-90

Babich, Babette. "Nietzsche and Eros: Between the Devil and God's Deep Blue Sea" Continental Philosophy Review. 33.2 (2000): 159-188.

Bataille, Georges. On Nietzsche. Trans. Bruce Boone. St. Paul: Paragon House, 1994.

----. The Bataille Reader. Ed. Fred Botting and Scott Wilson. Malden: Blackwell, 1997.

Beauvoir, Simone. The Second Sex. Trans. and Ed. H.M. Parshley. New York: Alfred A. Knopf, 1971.

Brobjer, Thomas H. "Nietzsche's Affirmative Morality: An Ethics of Virtue" The Journal of Nietzsche Studies 26 (2003) 64-78

Bulfinch, Thomas. Bulfinch's Mythology. New York: Modern Library, 1998.

Butler, Judith. Gender Trouble. New York: Routledge, 1999.

Darby, Tom. 'On Spiritual Crisis, Globalization and Planetary Rule' in Faith, Reason, and Political Life Today. Eds. Peter Lawler and Dale McConkey. New York: Lexington Books, 2001.

Deming, Richard. "Strategies of Overcoming: Nietzsche and the Will to Metaphor" Philosophy and Literature 28.1 (2004) 60-73.

Derrida, Jacques. Spurs. Chicago: University of Chicago, 1979.

Dodds, E.R. The Greeks and the Irrational. Berkeley: University of California, 1973.

Etymology Dictionary (Online). "Hysterical" Nov. 2001. Accessed on 23 May 2005.

http://www.etymonline.com/index.php?search=hysterical\&searchmode=none

Faulkner, Joanne. "Voices From the Depths: Reading 'Love' in Irigaray's Marine Lover" Diacritics 33.1 (2003) 81-94. 
Foucault, Michel. Language, Counter-Memory, Practice. Ed. Donald F. Bouchard. Trans. Donald F. Bouchard and Sherry Simon. Ithaca: Cornell University, 1977.

Graves, Robert. The Greek Myths. London: The Folio Society, 1999.

Heidegger, Martin. Nietzsche: Volumes One and Two. Trans. David Ferrell Krell. San Francisco: Harper Collins, 1979-1987.

Higgins, Kathleen Marie. 'Gender in The Gay Science' Philosophy and Literature 19.2 (1995) 227-247.

Hollingdale, R.J. Nietzsche: The Man and His Philosophy. New York: Cambridge University, 1999.

Irigaray, Luce. Marine Lover of Friedrich Nietzsche. Trans. Gillian C. Gill. New York: Columbia Universtiy, 1991.

---. This Sex Which is Not One. Trans. Catherine Porter. Ithaca: Cornell, 1985.

Irwing, Paul and Richard Lynn. "Sex differences in means and variability on the progressive matrices in university students: A meta-analysis" in The British Journal of Psychology 96:4 (2005) 505-524.

Kofman, Sarah. 'Baubo: Theological Perversion and Fetishism' in Nietzsche's New Seas. . Eds. Michael Allen Gillespie and Tracy B. Strong. pp.175-202.

Kristeva, Julia. Tales of Love. Trans. Leon S. Roudiez. New York: Columbia University, 1987.

Lackey, Michael. 'Killing God, Liberating the 'Subject:' Nietzsche and PostGod Freedom" Journal of the History of Ideas 60.4 (1999) 737-754

Lampert, Laurence. Nietzsche's Teaching. New Haven: Yale University, 1986

Nietzsche, Friedrich. Beyond Good and Evil. Trans. R.J. Hollingdale. Toronto: Penguin, 1990.

---. The Birth of Tragedy and other writings. Trans. Ronald Speirs Ed. Raymond Geuss and Ronald Speirs. New York: Cambridge, 2004.

---. The Case of Wagner. Trans. Walter Kaufmann. Amended by the Nietzsche Channel. Accessed online 15 July 2005. Available at http://www.geocities.com/thenietzschechannel/search.htm. 
---. The Gay Science. Trans. and Ed. Walter Kaufmann. Toronto: Vintage, 1974.

---. Homer's Contest. Trans. Walter Kaufmann. Amended by The Nietzsche Channel. Accessed on line 03 June 2005. Available at http://www.geocities.com/thenietzschechannel/hc.htm

---. Human, All too Human. Trans. Marion Faber and Stephen Lehman. Ed. Marion Faber. Lincoln: Bison, 1996.

----. "Letter's of Insanity" The Nietzsche Channel. Accessed on-line 12 May 2005. Available at http://www.geocities.com/thenietzschechannel/nilett7.htm

-.-. Nietzsche Contra Wagner.

---. On the Geneaology of Morals and Ecce Homo. Trans. Walter Kaufmann and R.J. Hollingdale (Genealogy only) and Ed. Walter Kaufmann. Toronto: Vintage, 1989.

---. The Portable Nietzsche. Trans and Ed. Walter Kaufmann. Toronto: Viking, 1976.

---. Twilight of the Idols. Trans. Thomas Common. Mineola: Dover, 2004.

---. The Will to Power. Trans. Walter Kaufmann and R.J. Hollingdale. Ed. Walter Kaufman. Toronto: Vintage, 1968.

Owen, David. "Equality, Democracy and Self-respect: Reflections on Nietzsche's Agonal Perfectionism" The Journal of Nietzsche Studies 24 (2002) 113-131

Plato. Republic. Trans. G.M.A Grube. Ed. C.D.C. Reeve. Indianapolis: Hackett, 1992.

---. Symposium. Trans. Christopher Gill and Desmond Lee. Toronto: Penguin, 1999.

Oliver, Kelly. "Nietzsche's Abjection" Nietzsche and the Feminine. Ed. Peter J. Burgard. Virginia: University Press of Virginia, 1994.pp. 53-67.

Plotnitsky, Arkady. "The Medusa's Ears: The Question of Nietzsche, The Question of Gender, and Transformations of Theory" Nietzsche and the Feminine. Ed. Peter J. Burgard. Virginia: University Press of Virginia, 1994. pp230-253.

Safranski, Rüdiger. Nietzsche: A Philosophical Biography. New York: Norton, 2003. 
Tirrell, Lynne. "Sexual Dualism and Women's Self-Creation: On the Advantages and Disadvantages of Reading Nietzsche for Feminists" Nietzsche and the Feminine. Ed. Peter J. Burgard. Virginia: University Press of Virginia, 1994. pp158-182

Touey, Daniel. "How Nietzsche Explains and Why" Journal of the History of Ideas 59.3 (1998) 485-498

Weeks, Mark. "Beyond a Joke: Nietzsche and the Birth of Superlaughter" The Journal of Nietzsche Studies 27 (2004) 1-17 